\title{
Hidasnémeti-Borház-dűlő Gravettien lelőhely kőpengéinek morfometriai elemzése
}

\author{
Eleki Ferenc, Péntek Attila
}

Kivonat

Abstract

Kulcsszavak

Keywords

Szerző • Author

Hivatkozás • Cite as
Hidasnémeti-Borház-dúlő felső paleolitikus lelőhely feltárását Simán Katalin vezette 1983-1985 között. A feltárások során előkerült leletanyagot az eszközkészletben előforduló vállas hegyek alapján kulturálisan a Gravettien kultúrkomplexum egy jól körülhatárolható korhorizontjába helyezte. A leletanyag technológiai szempontú elemzése Eleki (2010) publikálatlan szakdolgozatában található. A technológiai megközelítés segítségével a lelőhelyen megfigyelt két kultúrréteg kapcsolata új szempontból volt vizsgálható. A leletanyagban előforduló nagyszámú törés jelenléte pedig lehetőséget adott egy részletesebb metrikus vizsgálatra is. A lelőhely ilyen típusú elemzése korábban nem történt meg, az ásatások alapossága tette lehetôvé az ilyen irányú kutatásokat. Jelen írás célja a az Eleki (2010) szakdolgozatában található matematikai statisztikai vizsgálatok kibővítése. A lelőhely lehetséges funkciójának a kérdésével illetve a leletanyag régészeti értékelésével csupán érintőlegesen, a lehetőségek által kínált részletességgel kívánunk foglalkozni. A matematikai statisztikai vizsgálatok elvégzését azonban korántsem tekintettük öncélúnak, az eredményeket megpróbáljuk régészetileg interpretálni, még akkor is ha ez esetleg nem több mint hipotetikus elképzelés.

\section{Morphometric analysis of blades from Hidasnémeti-Borház-dűlő Gravettian site}

The excavation of Hidasnémeti-Borház dúlő Upper Palaeolithic site was conducted by Katalin Simán between 1983 and 1985. Based on the shouldered points in the excavated lithic assemblage, she placed the site to a well limited time horizon of the Gravettian technocomplex. Ferenc Eleki conducted a technological analyis on the assemblage in his unpublished MA thesis (Eleki 2010). With this technological approach, relationship of the two observed culture bearing layer became possible in novel ways. The presence of numerous „breakages” on blades and bladelets also offered an opportunity for a more detailed metrical analysis. This kind of analysis didn't took place so far, and only the thoroughness of the excavation could make possible to perform such studies. The one and only aim of this paper is the extension of the mathematical-statistical investigations. We would like to deal with the possible function of the site or the archaeological evaluation of the lithic assemblage only tangential. However, we didn't consider the completion of the mathematical-statistical investigations autotelic, we try to give an archaeological interpretation of the results, even if this is may be not more than a hypotetical notion.

Gravettien, felsô paleolitikum, matematikai statisztika, technológia, törések, Hidasnémeti

Gravettian, Upper Palaeolithic, mathematical statistics, technology, breakages, Hidasnémeti

Péntek Attila: attila.pentek@yahoo.com

Eleki, F. - Péntek, A. (2016) Hidasnémeti-Borház-dúlő Gravettien lelőhely kőpengéinek morfometriai elemzése. (Morphometric analysis of blades from Hidasnémeti-Borház-dűlő Gravettian site) Litikum 4: 29-44. https://doi.org/10.23898/litikuma0017

Kézirat történet • Article Érkezés | Received: 2016. 04. 19. Elfogadás | Accepted: 2016. 12. 20. Közzététel | Published: 2017.02 .15$. history

Jogok • Copyright

C 2016 Eleki-Péntek. Ez egy nyílt hozzáférésű publikáció, amit a Creative Commons 4.0 licensze véd. A termék szabadon használható, terjeszthető és sokszorosítható az eredeti szerző és forrás megjelölése mellett. | This is an open-access article distributed under the terms of the Creative Commons Attribution License, which permits unrestricted use, distribution, and reproduction in any medium, provided the original author and source are credited.

„Minden elég erôs, ellentmondásmentes elméletben van olyan mondat, mely eldönthetetlen, miközben igaz”. - Kurt Gödel első nemteljességi tételének episztemológiai vonatkozása

\section{Bevezetés}

Hidasnémeti település Északkelet-Magyarországon található, a Cserehát keleti lábánál, a Hernád völgyében. A felső paleolitikus lelőhely, Borház-dűlő, egy kis platón helyezkedik el 217 m tszf. magasságban, 17 méterrel a völgytalp felett. A feltárást Simán Katalin végezte 1983 és 1985 között. (Simán 1986; 1989) A régészeti leletanyag két szintben került elő, a vörös színú réteg alsó felében (30-65 cm), és $10 \mathrm{~cm}$-rel mélyebben a barna réteg középső részében (45-75 cm) (Simán 1989: 5-6). Simán Katalin véleménye szerint felmerülhetnek kétségek a két szint önállósága kapcsán, azonban meggyőző, hogy a két szintet egy steril réteg választotta el, és eltérő üledékből kerültek elő. Az ásató vizsgálatai alapján a két kultúrréteg leletanyaga techno-tipológiai alapon nem választható el egymástól. A talajtani körülmények miatt szerves anyagok alig maradtak fenn, így ${ }^{14} \mathrm{C}$ vizsgálatokra nem volt lehetőség.

Simán Katalin Hidasnémeti leletanyagát a Gravettien kultúrához sorolta, a lelőhely feltételezett korát(25-20 ka BP) csak az 
előzetes jelentésben említette (Simán 1986: 4). Magyarország területén a legközelebbi párhuzamainak BodrogkeresztúrHenye, Arka-Herzsarét és Pilismarót-Diós lelőhelyeket tartotta. A leletegyüttesek vizsgálata alapján azonban sem Bodrogkeresztúr-Henye, sem Arka-Herzsarét nem állt szoros kapcsolatban Hidasnémetivel (Simán 1989: 20). A három lelőhely közös vonása ugyanis az északi tűzkő előfordulása a retusált eszközök között. A Kárpát-medencén kívüli lelőhelyek közül Willendorf II/9, Dolní Věstonice, Kostienki 21, Kadar és Pavlov iparát tartotta hasonlónak (Simán 1989: 19-21).

A vállas hegyeket J. K. Kozłowski a késői Gravettienre jellemző kronológiai jelzőként és ugyanakkor a Gravettien központoknak a Pleniglaciális maximum előtti és az alatti eltolódásának taxonómiai jelzőjeként értelmezi (Kozłowski 2008: 182). A legkorábbi vállas hegyek Alsó-Ausztriában Willendorf II/9 rétegében fordulnak elő, amelynek radiokarbonos dátuma 24 910 $\$ 300$ (Haesearts et al. 1996).

A vállas hegyek horizontja (25-20 ka BP), J. Svoboda megfogalmazásában a Willendorfien-Kostienkien (Svoboda 1996: 288; 2007: 207). Új tipológiai elem a Kostienkien típusú vállas hegy, amely egy új nyelezési eljárás megjelenését jelzi, illetve a Kostienkien típusú kések, vagy bármilyen pengeeszköz, amelyen a Kostienkien technika megjelenik (Kozłowski 1998: 131). Alsó-Ausztriában és Morvaországban 25 ka BP után a korábbi időszakhoz viszonyítva megritkulnak a települések. A 25-20 ka BP közötti időszakban a radiokarbon adatai alapján (25 221 280 - $21200 \pm 1100$ BP ) tartós, hosszabb távú megtelepülésre utaló Milovice I lelőhely mellett (Musil 2010: 11) átmeneti vadásztelepek is megjelennek (pl. Kůlna-barlang 6 . réteg). Ez utóbbi jelenséget J. K. Kozłowski részben a népesség csökkenésével, részben a megnövekvő szezonális mobilitással magyarázza (Kozłowski 2008: 183).

A központi települések Nyugat-Szlovákiába, a Vág és Nyitra folyók völgyébe, továbbá Sziléziába és Dél-Lengyelországba, Krakkó környékére költöznek át (Kozłowski 1996: 18; 2008: 183). A klasszikus Kostienkien vonásokkal jellemezhető iparok, a csehországi Petřkovice és a szlovákiai lelőhelyek, Trenčianské Bohuslavice, Moravany-Lopata, MoravanyPodkovica, Nitra-Čermáň, Cejkov és Kašov alsó rétege 23,5-22 ka BP közé keltezhetőek (Verpoorte 2003: 6, Table 1; Verpoorte 2009; Kaminská, Kozłowski 2011: 6; Vlačiky et al. 2013: 47, Table 1.). A dél-lengyelországi lelőhelyek, mint Jaksice II, Kraków-Spadzista B-F, Kraków-Zwierzyniec, Witkowice hasonló korúak (Kozłowski 2008: 184; Wilczyński-Wojtal 2011; Wilczyński et al. 2012: 3630, Table 1; 2015: 97, Table 1). 22 ka BP után a Kostienkien jelleg fokozatosan eltűnik, már ritka a Kostienkien elem, illetve ezek atipikus formái bukkannak fel. A nyersanyag-felhasználásban a korábbi jó minőségú lengyelországi tưzkőféleségek helyett inkább a helyi nyersanyagok kerülnek előtérbe (Kozłowski 1998: 132).

T. Dobosi Viola a Pavlovien fiatalabb telepei közé sorolja be Hidasnémetit (T. Dobosi 2005, 62), és a korát nagyjából 25-24 ka BP körülre teszi (T. Dobosi 2009: 23). Ennek oka, hogy az ő rendszerében a vállas hegyek horizontja a Pavlovien legfiatalabb fázisa (T. Dobosi 2000a: 82). Lengyel György egy új, részletesebb tipológián alapuló beosztást vázolt fel a Gravettien entitás számára. A 25-20 ka BP közötti időszak a késői
Gravettien, amely három további csoportra osztható aszerint, hogy levélhegyet, vállas hegyet és tompított lamellát tartalmaz. Magyarországon a vállas hegyet tartalmazó késői Gravettient Hidasnémeti-Borház-dűlő képviseli (Kozłowski 2013; Lengyel 2014: 333-334, 340).

A lelőhely 3881 darabból álló leletanyagának részleges tipológiai, technológiai és morfometriai feldolgozása már megtörtént (Eleki 2010). A továbbiakban a leletanyag jellemzőire vonatkozó megjegyzések döntően ebből a szakdolgozatból származnak. A technológiai vonatkozású alapadatok ismertetése meghaladná a jelen cikk terjedelmét, ezért közlésüktől eltekintünk. Az egyes táblázatok megtalálhatók a hivatkozott szakdolgozat technológiai kérdéseket tárgyaló alfejezetében (Eleki 2010: 24-33).

\section{A leletegyüttes leírása}

\subsection{Nyersanyagfelhasználás}

Hidasnémeti-Borház-dűlő 3881 darabból álló feldolgozott leletanyaga a felhasznált nyersanyag szempontjából rendkívül homogén (Eleki 2010: 14, I. táblázat). A leletek döntő többsége (98,79 \%) helyi eredetű hidrokvarcit. Hidasnémeti esetében vastag patinaréteg fedi ezeket a darabokat. Ez a patina az anyag túlnyomó többségének fehér színt kölcsönöz, enyhe sárgás árnyalattal és barna pettyekkel, foltokkal. Kevésbé jellemző a szürke szín, ugyancsak barna foltokkal. Törésén leggyakrabban matt sötétszürke színű, kékes árnyalatú, sima felületû. Lemezes szerkezete, rétegzettsége különösen a kéreghez közeli, zárványosabb, rosszabb minőségú részek esetében figyelhető meg. A kérges felülettel rendelkező darabok nagy arányban fordulnak elő (21,23\%), ez a kéreg minden esetben barna színü, porózusos szerkezetú, legtöbbször igen vastag. Ennek a nyersanyagnak a minősége változó, vannak láthatóan jó pattintási tulajdonsággal rendelkező részek, de gyakoriak a zárványos, többszörösen rétegzett felületek is. A lelőhelyen felhasznált hidrokvarcit elsődleges geológiai forrása nem ismert, Magyarországon belül az Északi-középhegység teljes területén gyakori (T. Biró 2008a: 19). Az A. Přichystal nyomán limnoszilicitnek nevezett hidrotermális és limnikus eredetű kovás kőzeteknek az észak-magyarországi előfordulásával legutóbb Mester Zsolt és Faragó Norbert foglalkoztak. A cikkben a nyersanyagféleség geológiai előfordulásának és régészeti környezetben való felhasználásának a térképet is közölték (Mester, Faragó 2016: 36. Fig. 1). Borház-dúlő leletanyagának szerves maradványokban gazdag hidrokvarcitja Simán Katalin véleménye alapján valószínúleg a lelőhelyhez legközelebb eső geológiai forrásokból, a Zemplén-hegység területéről, illetve a Bükk-hegység déli részéről származik (Simán 1986: 2).

A többi nyersanyagféleség geológiai forrásai és beszerzési területei és a felhasznált nyersanyag-féleségek tekintetében a lelőhely nyersanyag-felhasználása igen változatos képet mutat (T. Biró 1986; 1988; 2008a; 2008b; Williams-Thorpe et al. 1984; 1987; Pelikán 1986; 2002). A hidrokvarcittól különböző nyersanyagok azonban a leletegyüttesben összesen csupán 1,21\%-ban képviseltetik magukat. 
A kvarcit minden valószínúséggel a lelőhely közvetlen környezetéből, a Hernád folyó hordalékából származik. Az enyhén érdes felületű, fehéres-sárgás színű kővelő (átkovásodott kaolinos agyag) geológiai forrása a Tokaji-hegység déli részén ismert. A Bükk-hegység területéről, a lelőhelytől mintegy 70 km távolságról származik a kvarcporfír. A kárpáti II-es típusú obszidián forrása az Eperjes-Tokaji hegység déli és középső részén található, a lelőhelytől mintegy 40-45km távolságra. A radiolarit esetében makroszkóposan nem dönthető el egyértelmúen az eredet. Amennyiben szlovákiai eredetű, akkor valószínúleg a lelőhely közeléből, a Hernád folyó hordalékából származik. A különböző radiolaritféleségek és radioláriás nyersanyagok ugyanakkor a Bükk hegység területén számos helyen, a legkülönbözóbb geológiai formációkban is megtalálhatóak. Ezek távolsága a lelőhelytől 60-70 km.

Ki kell emelni a távolsági nyersanyagok, a volhíniai és erratikus eredetű tűzkő előfordulását. Ezek beszerzési területei a lelőhelytől mintegy 370 km (Kremenets, Ukrajna) illetve 400 km (Felső-Szilézia, Lengyelország) távolságra találhatók.

Az eszközök esetében a hidrokvarcit aránya valamivel alacsonyabb (96,42 \%), a hidrokvarcittól eltérő nyersanyagok aránya valamivel magasabb (3,58 \%), a messzebbről beszerzett, jó minőségű nyersanyagok elsősorban eszközök formájában vannak jelen (Simán 1989: 13, 19, 4. Táblázat; Eleki 2010: 14, I. táblázat).

\subsection{Tipológia}

A hidrokvarcitra jellemző patina sok esetben megnehezítette a típusok meghatározását, jellemzően a marginális retusok és az egyszerú sérülések megkülönböztetését befolyásolta.

A lelőhelyen előforduló eszköztípusokat Eleki Ferenc (2010: 19) II. táblázata foglalja össze. A táblázat összehasonlítja a teljes leletanyag és az 1985-86-os ásatások során előkerült leletanyag összetételét. A táblázatban szétbontva szerepelnek az I. és a II. kultúrrétegek adatai is. Ezek tipológiai szétválasztásával, szétválaszthatóságával Simán Katalin már részletesen foglalkozott, a szintek kumulatív görbéjét is felrajzolta, és egymással összehasonlította (Simán 1989: 10-11, 5. ábra). Megállapítása szerint noha a második szintet arányaiban sokkal kevesebb lelet alkotja, tipológiai szempontból nem lehet különbséget tenni közöttük.

A 291 db vizsgálatba vont retusált eszköz közül a vésők (44 db, 15,12 \%) egy része többszörös véső. Többségük esetében a vésőleválasztást törésen végezték (burin sur cassure). Megtalálhatók a dihedrális, burin dièdre típusú (19 db) eszközök, amelyek egy részénél többszörös vésőleválasztásokat találunk, illetve a csonkításon készült (10 db, burin sur troncature) eszközök is. A csonkításon készült vésők esetében a csonkítást szinte minden esetben a szupport disztális végén hozták létre, és többnyire egyenes vonalú.

A $30 \mathrm{db}$ vakaró aránya 10,31 \%. Döntő többségük (26 db) penge szupporton készült, ezek közül 6 db oldaléle is retusált. Három darab készült szilánk szupporton, ezek egyikének oldaléle retusált , egy darab pedig gerincpengén. A szupport proximális vége 11 esetben, disztális vég 1 esetben törött. A leletanyagban egyetlen kettősvakaró található. A vakaróél helyének megválasztása határozott következetességet mutat, 22 esetben a disztális (73,33\%), 7 esetben a proximális végen hozták létre.

Tipikus a különféle hegyek jelenléte. A Gravette-hegyek (6 db, 2,06 \%) jelenléte minden kétséget kizáróan mutatja az együttes kapcsolatát a Gravettien kultúrkomplexummal. A hosszuk 27-68 mm, szélességük 5-18 mm között változik. Az átlaghosszúság $41 \mathrm{~mm}$, az átlagszélesség 12,17 mm. Méreteikben nem különösebben standardizáltak, a hosszúságadatok szórása 14,34 mm, a szélességé 4,4 mm. Valamennyi darabnak hiányzik a talonja, ugyanis törött pengén illetve lamellán alakították ki őket. A tompítás egy kivétellel minden esetben szinte teljesen egyenes. Két Gravette-hegy esetében is a hegyes vég végső kialakításánál bifaciális retust alkalmaztak.

A vállas hegyek (6 db, 2,06 \%) változatos formájúak, nem a klasszikus Kostienkien típusba tartoznak, legtöbbjük atipikus. Hosszuk jelentősen meghaladja a Gravette-hegyek hoszszát, 44-65 mm között változik, az átlagos hosszúság $52 \mathrm{~mm}$, a szórás csak 7,64 mm. Szélesebbek a Gravette-hegyeknél, a szélesség 13-25 mm között változik, az átlagos szélesség 17,67 mm, a szórás $4,37 \mathrm{~mm}$. A szupport kiválasztásánál minden valószínúség szerint más szempontokat vettek figyelembe, mint a Gravette-hegyek esetében. Egyetlen kivételtől, egy kortexes talontól eltekintve, hiányzik a darabok talonja. Ez a leghosszabb darab (65 mm), szélessége ugyanakkor csak 15 mm. A többihez képest kiugróan karcsú, a legnagyobb hoszszúság/szélesség mérettel rendelkezik, vagyis a többitől feltûnően eltérő darabról van szó. A Gravette-hegyek és vállas hegyek közötti morfológiai különbségek minden bizonnyal a felhasználással függhetnek össze.

A következő népesebb eszköztípust a tompított hátú lamellák (13 db, 4,47 \%), és hozzájuk szorosan kapcsolódva a tompított hátú pengék ( $5 \mathrm{db}, 1,72 \%$ ) képviselik. A tompított hátú lamellák mind töröttek, és túlnyomó részt mindkét végükön (64,29 \%). Az esetek majdnem felében a tompítással szembeni élen is előfordul valamilyen retus (42,86 \%). A tompított hátú pengék ugyancsak töröttek.

A fenti típusokon kívül szinte elhanyagolható számban jelennek meg fogazott eszközök (3 db, 1,03 \%) és kaparók ( 2 db, $0,69 \%$ a leletanyagban. Az utóbbiak közül az egyik darab egy keresztélü kaparó.

A retusált eszközök nagy részét az egyszerű retusált pengék teszik ki (53,61\%). A pengéken előforduló retusok nagy variabilitást mutatnak, de általánosan jellemző a direkt, normál, marginális és rövid retus. Vagy a jobb, vagy a bal élt retusálták egy rövidebb szakaszon. A nyelezés (2 db) és a vállazás (29 db, a retusált pengéken belül 18,47\%) speciális nyelezési technikákra utalnak, ezért különös jelentőségük van. Emellett előfordulnak völgyelések ( $25 \mathrm{db}$, a retusált pengéken belül 15,92 \%). A retusált pengék közül csupán 5 darabot tekintünk retusált lamellának (1,72\%). Ezek alacsony aránya a tompított hátú lamellákhoz képest igen feltünő. Csak négy lelet esetében beszélhetünk csonkításról. A retusált szilánkok természetesen a legváltozatosabb formákat képviselik, jellemző, hogy igen nagy számban fordul elő kérges szupport (52,38 \%). 


\subsection{Technológia}

A leletanyag technológiai vonatkozásait itt csak érintőlegesen tárgyaljuk, elsősorban a pengék kapcsán, amelyek az elvégzett morfometriai elemzések központjában állnak. A leletanyagban előforduló szokatlanul nagyszámú törés jelenléte, továbbá az ebből adódó következtetések tették szükségessé az Eleki Ferenc szakdolgozatában megkezdett elemzések folytatását és kiterjesztését (Eleki 2010).

A szilánkok és a pengék előállításának a koncepciója ugyan jelentősen eltér egymástól, de az alkalmazott technológiai eljárások egy folyamatnak az egymást követő részeit képezhetik. Abban az esetben amikor a leválasztásnak olyan a morfológiája, hogy a legnagyobb hosszúsága eléri vagy meghaladja a legnagyobb szélességének kétszeresét, akkor pengéről beszélünk (Inizan et al. 1995: 73, 149). Miután a penge definíciója nem foglalkozik azzal a kérdéssel sem, hogy a leválasztás milyen debitázs terméke, a vizsgálatok során bevezettük a „technológiai penge” fogalmát. Az olyan darabokat soroltuk a „technológiai” pengekategóriába, amelyek pengedebitázs eredményeképpen keletkeztek, de nem teljesül rájuk a fenti arány. Ezen a tágabb értelemben vett „technológiai” pengekategórián belül a morfometriai elemzések során elkülönítve vizsgáljuk a fenti formai elvet követő darabokat. A durvább szilánkok leválasztásánál gyakrabban használtak kemény ütőt, és a leválasztási irányoknál a magkövek megformálásához szükség volt körkörös és egymásra merőleges leválasztásokra. A két egymással szemben lévő leválasztási felszínnel rendelkező magkövekről történő leválasztás kifejezetten a pengék előállításánál tipikus.

A lelőhelyen egyértelmúen a penge szupportot preferálták. $\mathrm{Az}$ eszközöket szinte kizárólag pengéken, illetve nyújtott, pengeszerú szilánkokon alakították ki. A pengék morfológiailag általában enyhén íveltek és háromszög keresztmetszetűek, vagyis a vezetőborda szinte minden (ideális) esetben középen végigfut a pengén. A leletanyagban gyakran előforduló jelenségek a különböző pattintási hibák (Eleki 2010: 2829, 8-11. ábra). A Siret-törés csak néhány leleten bukkan fel, és gyakoribb szilánkokon, mint pengéken. A túlfutott pattintási hiba szinte csak a pengékre jellemző, a szilánkok esetében ritka. Csapott hiba már hasonló arányban fordul elő szilánkokon és pengéken, bár valamivel gyakoribb az utóbbin. A csapott darabok viszonylag sürün megjelennek az anyagban, de igazán nagy tömegben nyelv alakú törésekkel találkozhatunk. A nyelv alakú törésekkel egyáltalán nem foglalkoztak, a túlfutott, Siret-törést szenvedett és csapott pengéket ritkán használták fel szupportként.

A leletanyagban igen nagyszámú törés fordul elő, az általunk megvizsgált 828 darab penge esetében az arány $84,3 \%$. Az elemzésbe bevont 291 darab eszköz nagyobb része (236 db, $81,1 \%$ ) is törött szupporton készült. Vagyis ez ugyancsak arról tanúskodik, hogy a szupport kiválasztásánál nem számított az adott darab törött vagy ép jellege.

\section{Matematikai-statisztikai alapok}

\subsection{Valószínűségi eloszlások}

A matematikai-statisztikai elemzések előtt a matematikai részletek mellőzésével néhány megjegyzést kell tennünk néhány, a későbbiekben tárgyalt, a gyakorlatban gyakran előforduló valószínúségi eloszlásról, továbbá azok jellemzőiről. Valamennyi matematikai-statisztikai fogalom és a röviden ismertetendő módszerek részletes leírása megtalálható elektromos formában is az interneten (NIST 2013).

\subsubsection{Normális (Gauss-) eloszlás}

A normális eloszlás talán a legfontosabb eloszlás mind a valószínúségszámításban, mind a matematikai-statisztikában. A központi határeloszlás tétel értelmében ha egy valószínűségi változó értékét nagyszámú, egymástól függetlenül ható véletlen tényező határozza meg, úgy hogy az egyes tényezők külön-külön csak igen kis mértékben járulnak hozzá az összes véletlen hatásból eredő ingadozáshoz, és az egyes tényezők hatásai összeadódnak (additivitás), akkor általában normális eloszlású valószínűségi változót kapunk. A normális eloszlású valószínűségi változók fontos tulajdonsága hogy a összegük is normális eloszlású. És megfordítva is igaz: ha $\mathrm{X}_{1}$ és $\mathrm{X}_{2}$ független valószínúségi változó, és $\mathrm{X}_{1}+\mathrm{X}_{2}$ normális eloszlású, akkor $\mathrm{X}_{1}$ is és $\mathrm{X}_{2}$ is normális eloszlású.

\subsubsection{Lognormális eloszlás}

A lognormális eloszlás egy folytonos valószínúség eloszlás, amelyre az jellemző, hogy a valószínűségi változó logaritmusa normális eloszlású. A lognormális eloszlású valószínűségi változó csak pozitív valós értéket vehet fel. Közelítőleg lognormális eloszlást követnek azok az értékek, melyek (minél) több, egymástól független véletlen, szorzódó hatásból (multiplikativitás) származtathatóak. Több, egymáshoz viszonylag közeli átlagos értékkel és szórással rendelkezô normális eloszlást összegezve a nyert eloszlás lognormális eloszlás lesz. A lognormális eloszlás igen elterjedt mind a társadalomtudományok mind a természettudományok területén. Egy véletlenszerüen végzett kőzetdaraboláskor a kapott darabok mérteloszlása jó közelítéssel lognormális.

\subsubsection{Multimodális eloszlás}

A módusz egy adathalmaz leggyakoribb elemét jelenti. A valószínúségszámítás terminológiájával kifejezve egy folytonos valószínúségeloszlás jellemző adata, olyan pont, ahol az eloszlás sűrüségfüggvényének lokális maximuma van. Egy eloszlásnak több módusza is lehet. Az ilyen több lokális maximummal rendelkező eloszlásokat multimodális eloszlásoknak nevezzük. Ha két normális eloszlás várható értékére és (közös) szórására fennáll, hogy abs $(\mu 1-\mu 2)>2 \sigma$, ha tehát a normális eloszlások jól szeparáltak, akkor az összegzés által nyert eloszlás bimodális eloszlás lesz. Általában igaz a megállapítás, hogy a multimodális eloszlás inhomogén mintára, következésképpen valószínűsíthetően inhomogén populációra utal. 


\subsubsection{A valószinüségi eloszlások néhány jellemzôje}

A csúcsosság az eloszlásgörbének a normális eloszlás görbéjéhez viszonyított hegyesebb, csúcsosabb vagy laposabb jellegét méri. A mérték definíciója folytán normális eloszlás esetén az értéke nulla, pozitív érték csúcsosabb (leptokurtikus) görbére, negatív érték laposabb (platikurtikus) görbére utal. Ez utóbbinak extrém esete az egyenletes eloszlás.

A ferdeség az eloszlás ferdeségére vonatkozó statisztika, a szimmetria, pontosabban a szimmetria hiányának a mértéke. Egy eloszlást vagy adathalmazt értelem szerint akkor tekintünk szimmetrikusnak, ha a központi tengelyének bal és jobb oldala egymáshoz hasonló. A normális eloszlás és minden szimmetrikus adathalmaz ferdesége 0. Negatív esetben az eloszlás balra ferde. A negatív érték azt jelenti, hogy a görbe bal oldali farokrésze a jobb oldali farokrészhez viszonyítva hosszabb, azaz kevésbé meredek. Pozitív esetben jobbra ferde. Pozitív érték esetében a görbe jobb oldali farokrész a bal oldali farokrészhez viszonyítva hosszabb, azaz kevésbé meredek. Érthetőbbé téve ennek a mértéknek a jelentését, a baloldali szimmetria úgy képzelhetó el, hogy az ismérvértékek többsége átlag alatti, a jobb oldali szimmetria esetén pedig átlag feletti. A lognormális, és a hozzá hasonló eloszlások mind jobbra ferde eloszlások.

\subsection{Illeszkedésvizsgálat}

Valamennyi matematikai-statisztikai vizsgálat kezdetekor felmerülő probléma az illeszkedésvizsgálat. Ennek során egy változó feltételezett eloszlását ellenőrizzük valamely hipotézisvizsgálat segítségével. A hipotézisvizsgálat mint próba nullhipotézise szerint egy adott sokaság eloszlása megközelítőleg a feltételezett eloszlást követi. A statisztikai elemzéseknél alkalmazott egyes módszerek feltételezik a modell valamely adott változójának normális eloszlását. Noha a legtöbb módszer elég „robusztus” erre a feltételezésre, ajánlatos ellenőrizni, hogy egy változó megközelítőleg normális eloszlást követ-e. Ha egy adott változó normális eloszlását vizsgáljuk, akkor normalitásvizsgálatról beszélünk.

A különböző vizsgálati módszerek gyakran egymástól eltérő eredményt szolgáltatnak („diagnózis konfliktus”), attól függôen, hogy az eloszlás görbéjének mely részével (a centrális résszel illetve a farokrészekkel) illetve az eloszlás mely momentumával (ferdeség, csúcsosság) foglalkoznak.

A Pearson-féle $\chi 2$ próba diszkrét eloszlású változók vizsgálatára alkalmas statisztikai eljárás. A próbával két kvalitatív változó függetlenségét, vagy az egyik függését a másiktól vizsgáljuk. A lognormalitás tesztelésére kizárólag ezt a módszert alkalmazzuk. Ennek az az oka, hogy számos más, a lognormális eloszlás eloszlásfüggvényére hasonlító eloszlás létezik. A lognormalitásra vonatkozó \2 próba elvégzését követően $\chi 2$ próbával elvégezzük a normalitás ellenőrzését is.

Különösen hatékonynak tekintik az eloszlásgörbe ferdeségén és csúcsosságán alapuló vizsgálati módszereket. Miután az eljárások érzékenyek a minta nagyságára, a számos rendelkezésre álló módszer közül a normalitás ellenőrzésére a Jarque-Bera-féle omnibusz teszt (Jarque-Bera 1980: 163-172), és a D'Agostino-Pearson-féle omnibusz teszt (D'Agostino 1970; D’Agostino et al. 1990) elvégzését részesítettük előnyben.

A gyakorlatban igen elterjedt a Kolmogorov-Szmirnovpróba (Chakravarti, Laha 1967, 392-394) alkalmazása, amely már viszonylag kisebb minta esetén (elemszám \pm 50 ) is alkalmazható, ugyanakkor eléggé érzékeny a mintában előforduló esetleges extrém értékekre. A próba az ún. nem-paraméteres próbák közé tartozik, amelyek nem kívánnak meg különösebb feltételeket a változók eloszlásáról. Igen stabil, alkalmas nem folytonos eloszlások vizsgálatára is. Eloszlásfüggetlen, nem csak normális eloszlásból származó statisztikák vizsgálatára alkalmas. A Kolmogorov-Szmirnov-próba egy erősebb változata csak normális eloszlásokra a Lilliefors-próba (Lilliefors 1967: 399-402) vagy másképpen Lilliefors-féle szignifikancia korrekció. A próbát a logaritmikus adatok normalitásának ellenőrzésére valamennyi esetben elvégeztük. Miután a próba eredményei egyértelműen összhangban voltak a $\chi 2$ próba és az omnibusz tesztek eredményeivel, így a táblázatokban mellőztük az ismertetésüket.

\section{Matematikai-statisztikai elemzések a ma- gyarországi paleolitkutatásban}

Paleolitkutatásunkban elsőként Vértes László alkalmazta a különböző matematikai-statisztikai módszereket Arka felső paleolitikus lelőhely leletanyagának elemzésekor (Vértes 1964). Az elemzései közül jelen cikk szempontjából a legnagyobb eszmei jelentőséggel a leletegyüttesben található 1159 penge vizsgálata tekinthető. Megállapítása szerint a mintaelemek mérete lognormális eloszlást követ. Felismeri, hogy ennek oka lehetne a véletlen darabolódás is. Feltételezett funkcionális eltérések szerinti méretcsoportokra osztva, egy-egy csoporton belül a méreteloszlás normális. Miután a lelőhely mühely jellege folytán a pengék nagy számban történő készítése valószínüsíthető, a normális eloszlás fellépése várható volt (Bosznay 2008: 10). Boldogkőváralja neolitikus penge-depotjának elemzése során (Vértes 1965) hivatkozik az arkai anyag elemzésére, kihangsúlyozva a mintaelemek funkcionális különbségének fontosságát. Matematikai szempontból helytálló módon megállapítja hogy a pengék méretének lognormális eloszlása viszonylag közeli átlagos értékkel és szórással rendelkező normális eloszlások összegződése által keletkezett. A hangsúly itt a normális eloszlások viszonylag közeli paraméterein van. A neolitikus penge-depot esetében a pengék „standardizált” jellegénél fogva a normális eloszlás matematikai-statisztikai igazolása megfelelt a várakozásoknak.

Vértes László munkásságát követően meg kell említeni Nagy Gergely diplomamunkáját (Nagy 2013), amelyben a Simán Katalin által feltárt Avas Alsó-Szentgyörgy lelőhely leletanyagának egy részét vizsgálta kiterjedt matematikai-statisztikai módszerekkel. A morfometriai vizsgálatai miatt megemlíthetők Mester Zsoltnak a magyarországi középső és felső paleolitikum bifaciális levéleszközeinek technológiájával foglalkozó cikkei (Mester 2008-2009; 2010; 2011). Legutóbb Lengyel György és Wei Chu foglalkozott a késői Gravettien pengedebitázzsal kapcsolatban az ütő és a leválasztott pengék metrikai adatai közötti összefüggés kérdésével (Lengyel, Chu 2016). 


\begin{tabular}{|c|c|c|c|c|c|c|c|c|c|c|c|}
\hline \multicolumn{2}{|c|}{ Hosszúság } & $\#$ & Átlag & Szórás & $\begin{array}{r}\text { Var. } \\
\text { Koeff. \% }\end{array}$ & $\begin{array}{l}\text { Mini- } \\
\text { mum }\end{array}$ & Medián & Módusz & $\begin{array}{l}\text { Maxi- } \\
\text { mum }\end{array}$ & $\begin{array}{r}\text { Csúcsos- } \\
\text { ság }\end{array}$ & Ferdeség \\
\hline \multicolumn{2}{|c|}{ Ép pengék (technológiai) } & 130 & 49,76 & 22,99 & 46,21 & 15 & 46,00 & 27,00 & 110 & 0,13115 & 0,78162 \\
\hline \multicolumn{2}{|c|}{ Ép pengék (2:1 arány) } & 85 & 58,46 & 21,75 & 37,21 & 26 & 54,00 & 53,00 & 110 & $-0,13987$ & 0,77374 \\
\hline \multirow{6}{*}{$\begin{array}{l}\text { Törött } \\
\text { pengék }\end{array}$} & Összes & 689 & 33,50 & 14,82 & 44,25 & 8 & 32,00 & 32,00 & 102 & 1,39937 & 1,00119 \\
\hline & $\begin{array}{l}\text { Sima tö- } \\
\text { résfelület }\end{array}$ & 529 & 33,27 & 14,69 & 44,15 & 8 & 31,50 & 22,00 & 102 & 1,76719 & 1,07114 \\
\hline & $\begin{array}{l}\text { Nyelv ala- } \\
\text { kú törés }\end{array}$ & 160 & 34,26 & 15,29 & 44,63 & 8 & 32,50 & 20,00 & 84 & 0,43475 & 0,79469 \\
\hline & $\begin{array}{l}\text { Disztális } \\
\text { vég törött }\end{array}$ & 254 & 33,12 & 14,21 & 42,90 & 8 & 32,00 & 32,00 & 97 & 1,35997 & 0,92812 \\
\hline & $\begin{array}{l}\text { Mindkét } \\
\text { vég törött }\end{array}$ & 234 & 30,23 & 13,87 & 45,89 & 8 & 27,00 & 22,00 & 82 & 0,71520 & 0,93559 \\
\hline & $\begin{array}{l}\text { Proximális } \\
\text { vég törött }\end{array}$ & 201 & 37,78 & 15,66 & 41,44 & 10 & 35,00 & 27,00 & 102 & 1,66965 & 1,12048 \\
\hline
\end{tabular}

1. táblázat. Az ép és törött pengék hosszúságadatainak statisztikai jellemzői. // Table 1. Broken and whole blades length statistics.

\begin{tabular}{|c|c|c|c|c|c|c|c|c|c|c|c|}
\hline \multicolumn{2}{|c|}{ Szélesség } & $\#$ & Átlag & Szórás & $\begin{array}{r}\text { Var. } \\
\text { Koeff. \% }\end{array}$ & $\begin{array}{l}\text { Mini- } \\
\text { mum }\end{array}$ & Medián & Módusz & $\begin{array}{l}\text { Maxi- } \\
\text { mum }\end{array}$ & $\begin{array}{r}\text { Csúcsos- } \\
\text { ság }\end{array}$ & Ferdeség \\
\hline \multicolumn{2}{|c|}{ Ép pengék (technológiai) } & 130 & 22,12 & 7,68 & 34,72 & 9 & 21,00 & 22,00 & 54 & 1,95802 & 1,10351 \\
\hline \multicolumn{2}{|c|}{ Ép pengék (2:1 arány) } & 85 & 20,72 & 6,21 & 29,96 & 9 & 20,00 & 22,00 & 38 & $-0,03896$ & 0,53467 \\
\hline \multirow{6}{*}{$\begin{array}{l}\text { Törött } \\
\text { pengék }\end{array}$} & Összes & 689 & 21,17 & 8,13 & 38,42 & 8 & 20,00 & 18,00 & 80 & 4,80785 & 1,53042 \\
\hline & $\begin{array}{l}\text { Sima tö- } \\
\text { résfelület }\end{array}$ & 529 & 21,01 & 8,35 & 39,72 & 8 & 19,00 & 17,00 & 80 & 5,59135 & 1,67633 \\
\hline & $\begin{array}{l}\text { Nyelv ala- } \\
\text { kú törés }\end{array}$ & 160 & 21,71 & 7,39 & 34,04 & 9 & 20,50 & 22,00 & 46 & 0,74121 & 0,88799 \\
\hline & $\begin{array}{l}\text { Disztális } \\
\text { vég törött }\end{array}$ & 254 & 20,83 & 7,54 & 36,20 & 8 & 19,00 & 18,00 & 50 & 2,57640 & 1,43114 \\
\hline & $\begin{array}{l}\text { Mindkét } \\
\text { vég törött }\end{array}$ & 234 & 20,90 & 7,72 & 36,93 & 8 & 20,00 & 20,00 & 48 & 0,56709 & 0,88380 \\
\hline & $\begin{array}{l}\text { Proximális } \\
\text { vég törött }\end{array}$ & 201 & 21,94 & 9,25 & 42,15 & 9 & 20,00 & 19,00 & 80 & 7,72631 & 1,94629 \\
\hline
\end{tabular}

2. táblázat. Az ép és törött pengék szélességadatainak statisztikai jellemzői. //

Table 2. Broken and whole blades width statistics.

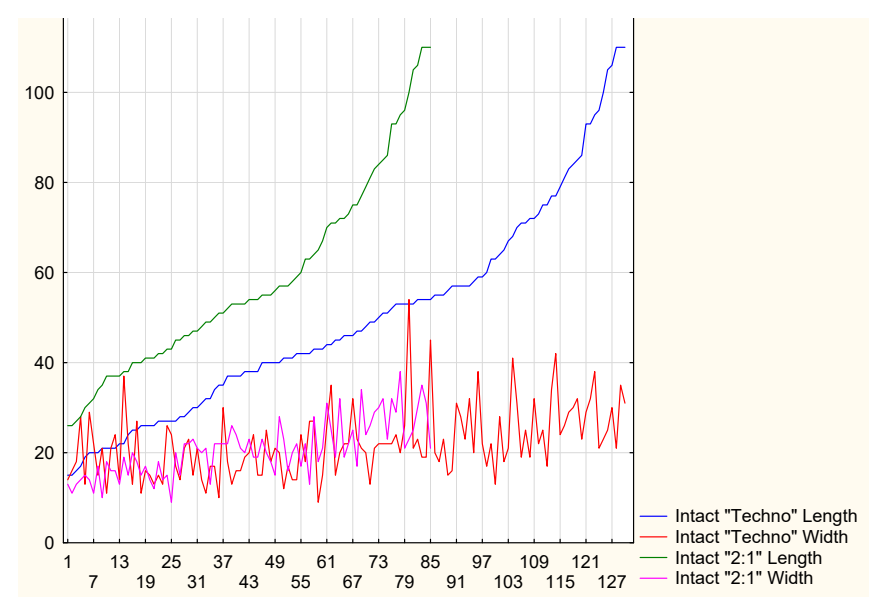

1. ábra. Az ép pengék hosszúság- és szélességadatai. Figure 1. Whole blades, length and width data.

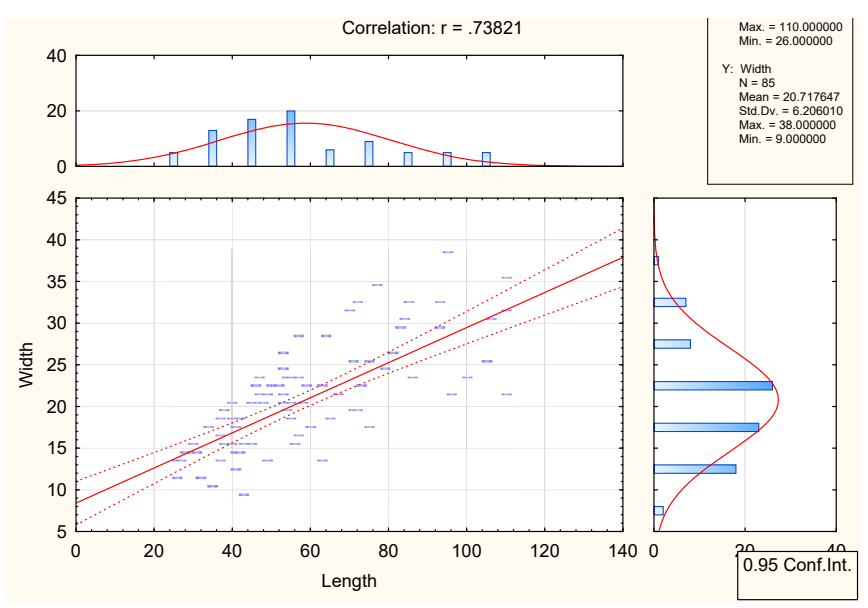

2. ábra. Az ép „2:1" pengék hosszúság- és szélességadatainak szóródási diagramja.

Figure 2. Whole "2:1" blades, length and width data scattergram. 


\section{A metrikus adatok matematikai-statiszti- kai elemzése}

A vizsgálat alá vont alapvető morfometriai adatok, amelyekre a következő elemzések során gyakran az angol elnevezés első betưjével hivatkozunk, a maximális hosszúság (Length - L), a maximális szélesség (Width - W). A vizsgálatba nem vontunk be további morfológiai jellemzőket, sem a maximális vastagságot (Thickness - T), sem pedig olyan származtatott adatokat mint a hosszúság:szélesség (L/W) aránya. Nem célunk egy teljeskörü elemzés végrehajtása, és további adatok bevonása, azok gyakran ellentmondásos viselkedése folytán, megnehezítette volna az elemzések eredményeinek értékelését.

Az elvégzett matematikai-statisztikai vizsgálatokkal csupán azt a kérdést próbáltuk megválaszolni, hogy feltételezhető-e bármilyen morfológiával, metrikai arányokkal rendelkező pengék leválasztására. Létezett-e, és ha igen, akkor felismerhető-e valamilyen standardizációra mutató törekvés.

\subsection{Pengék}

Amint fent említettük, a matematikai-statisztikai elemzéseink fókuszában a pengék elemzése áll. Ennek oka kettős, egyrészt az összevontan kezelt leletanyagban igen jelentős a pengék illetve pengetöredékek száma, másrészt az eszközök jelentôs részét is penge szupporton készítették. Már Simán Katalin is felfigyelt az ép pengék viszonylag alacsony arányára. Három méretkategóriát különített el. A legnagyobb darabok hosszúsága eléri a $15 \mathrm{~cm}$-es nagyságot. Ezek általában keskeny, többé-kevésbé hajlott darabok. A következő méretkategória a közepes nagyságú, $6 \mathrm{~cm}$ átlagos hosszú pengék csoportja. Itt található az ép pengék többsége. A legkisebb méretcsoport a $3 \mathrm{~cm}$ átlagos hosszúságú kis méretű pengéket és lamellákat tartalmazza. Simán Katalin felfigyelt arra is, hogy a pengéket néhány esetben szándékosan törték el és eszközkészítés szupportjaként szolgáltak.

Ez a szándékos törési jelenség feltehetően az eszközök nyelezéséhez kapcsolódik. A pengék megmunkálását a lelőhely egyik „profiljának” tekintette. Nem foglalkozik ugyanakkor a pengék törésének okával és jellegével, természetével sem (Simán 1989: 11).

Az általunk vizsgált adatok némileg eltérnek Simán adataitól (Simán 1989: 10, Table 2). Az eltérés elsősorban a pengetöredékek esetében jelentősebb. Ennek valószínúsíthető oka módszertani jellegû, nála ugyanis magasabb a pengetöredékek közé sorolt, általunk viszont szilánktöredékként azonosított darabok száma. Az alapvető morfometriai adatok statisztikai jellemzőit az alábbi 1. és 2. táblázatok tartalmazzák.

\subsection{1. Ép pengék}

Amint fent a technológiai megjegyzések kapcsán utaltunk rá, az ép pengéket két kategóriába soroltuk. A tágabb értelemben vett „technológiai” pengekategórián (130 db) belül a morfometriai elemzések során elkülönítve vizsgáljuk a legnagyobb hosszúság és legnagyobb szélesség arányára vonatkozó „legalább 2:1 arány” formai elvet teljesítő darabokat (85 db).
Ez a megkülönböztetés látható az 1. táblázatban, az ép „technológiai" pengék átlaghosszúsága $8,7 \mathrm{~mm}$-el rövidebb mint a 2:1 arány figyelembevételével számolt átlaghosszúság. Mindkét kategóriában feltûnik a táblázatban a hosszúság viszonylag magas szórásértéke. A szélesség különbsége a kategóriák között sokkal kisebb és lényegesen kisebb a szórás értéke is. A hosszúsági és szélességi adatok együtt ábrázolhatósága végett az ép pengék adatait a hosszúság alapján rendeztük. Az 1. ábrán a két pengekategória adatait együtt ábrázoltuk.

A pengék hossza egy kezdeti kisebb ugrást követően fokozatosan nő, csak a végén kezd meredeken emelkedni. A pengék szélessége enyhén növekszik a hosszúság növekedésével, de láthatóan inkább egy sávban marad, egy adott mérettartományon belül mozog. A diagram jól szemlélteti a két morfológiai adat szórásértékei közötti különbséget.

A hosszúság és szélesség egymáshoz viszonyított szóródási diagramja a 2. ábrán látható az $\mathrm{L} / \mathrm{W} \geq 2: 1$ arányt teljesítő pengék esetére. Amint látható a méretadatok közötti korreláció értéke $\mathrm{r}=0,73821$, amely viszonylag erősnek tekinthető. $E z$ a tény egy adott L/W aránnyal rendelkezö, „standardizált pengék” készitésére utaló jelként értelmezhetô. Az ép „technológiai” pengék esetén, a fogalom tágabb volta folytán ez a korreláció lényegesen alacsonyabb, $\mathrm{r}=0,43553$.

A hosszúságadatokat 5-110 mm között, 21 darab egyenlő közű, 5 mm szélességú intervallum alapján gyakorisági csoportokba soroltuk. Az így csoportosított hosszúságadatok eloszlásgörbéje a 3. ábrán látható.

Látható, hogy a két eloszlásgörbe meglehetősen hasonló egymáshoz, a gyakorisági csoportok közötti korreláció értéke $r=0,79386$. Tulajdonképpen multimodális, több móduszú eloszlásgörbékkel van dolgunk. A nagyobb mintaelemszám miatt az ép „technológiai” pengék eloszlásgörbéje érthetően magasabb és az ugrások amplitúdója is nagyobb. Az eloszlásgörbék ugyanakkor ellentmondanak a pengék Simán féle három hosszúságkategóriába való sorolhatóságának. Látható hogy a pengék többsége az 5-10. hosszúsági intervallumba, 25-55 mm közé esik. A görbe másik maximumhelyét a 14. hosszúsági kategória, a 71-75 mm hosszú pengék jelentik.

A 3. és 4. táblázatban a hosszúságra és szélességre vonatkozó illeszkedésvizsgálat alapján az ép pengék méretei többé-kevésbé lognormális eloszlást követnek. Az ellenpróba ugyanezt igazolja, a logaritmikus adatok eloszlása normális eloszlású. A 130 db ép „techno” pengék közül 90 db (69,23 \%) a 21-60 mm hosszúságintervallumba, $104 \mathrm{db}$ (78,2 \%) a 11-31 mm szélességintervallumba esik. Az átlagértékek alapján az 49,76×22,12 mm mérettartomány tekinthető „idealizáltnak”. A fenti hosszúságintervallumba eső $90 \mathrm{db}$ penge átlagos L/W aránya 2,14, ami alig valamivel alacsonyabb mint az összes darabra vonatkozó átlag (2,34). Hasonlóak az arányok az ép „2:1” pengék esetén, a $85 \mathrm{db}$ közül $48 \mathrm{db}(56,47 \%)$ a 26-60 mm hoszszúságintervallumba, $67 \mathrm{db}$ (78,82 \%) a 11-25 mm szélességintervallumba esik. Itt a vonatkozó átlagos L/W arány 2,58, valamivel alacsonyabb, mint az összes darab átlagos értéke $(2,85)$. Az átlagértékek alapján az 58,46×20,72 mm mérettartomány tekinthető „idealizáltnak”. 


\begin{tabular}{|c|c|c|c|c|c|c|c|c|c|c|c|c|c|}
\hline \multirow{3}{*}{\multicolumn{2}{|c|}{$\begin{array}{c}\text { Illeszkedésvizsgálat } \\
\text { Hosszúság }\end{array}$}} & \multicolumn{4}{|c|}{ Lognormális } & \multicolumn{8}{|c|}{ Logaritmikus hosszúság normális } \\
\hline & & \multicolumn{4}{|c|}{$x^{2}$ próba } & \multicolumn{3}{|c|}{$x^{2}$ próba } & \multicolumn{3}{|c|}{ Jarque-Bera } & \multicolumn{2}{|c|}{$\begin{array}{l}\text { D'Agostino- } \\
\text { Pearson }\end{array}$} \\
\hline & & $\#$ & $x^{2}$ & df & $\mathrm{p}$ & $x^{2}$ & df & $\mathrm{p}$ & $J B$ & $\mathrm{p}$ (normal) & $\begin{array}{r}\mathrm{p} \text { (Monte } \\
\text { Carlo) }\end{array}$ & DP & $\mathrm{p}$ \\
\hline \multicolumn{2}{|c|}{$\begin{array}{l}\text { Ép pengék (tech- } \\
\text { nológiai) }\end{array}$} & 130 & 15,74008 & 10 & 0,10732 & 8,84965 & 10 & 0,54643 & 1,00000 & 0,60640 & 0,42220 & 2,50 & 0,2872 \\
\hline \multicolumn{2}{|c|}{ Ép pengék (2:1 arány) } & 85 & 11,29472 & 8 & 0,18555 & 9,59948 & 10 & 0,47631 & 0,81920 & 0,66390 & 0,50300 & 1,41 & 0,4939 \\
\hline \multirow{6}{*}{$\begin{array}{l}\text { Törött } \\
\text { pengék }\end{array}$} & Összes & 689 & 23,35680 & 11 & 0,01573 & 29,62660 & 12 & 0,00318 & 6,22200 & 0,04455 & 0,04490 & 6,20 & 0,0450 \\
\hline & $\begin{array}{l}\text { Sima tö- } \\
\text { résfelület }\end{array}$ & 529 & 19,79433 & 11 & 0,04824 & 27,08527 & 12 & 0,00751 & 3,89700 & 0,14250 & 0,12070 & 3,88 & 0,1434 \\
\hline & $\begin{array}{l}\text { Nyelv ala- } \\
\text { kú törés }\end{array}$ & 160 & 12,99656 & 9 & 0,16276 & 11,14711 & 10 & 0,34617 & 2,55100 & 0,27930 & 0,20960 & 2,54 & 0,2813 \\
\hline & $\begin{array}{l}\text { Disztális } \\
\text { vég törött }\end{array}$ & 254 & 13,18017 & 9 & 0,15462 & 26,17967 & 10 & 0,00351 & 3,19600 & 0,20230 & 0,16350 & 3,01 & 0,2218 \\
\hline & $\begin{array}{l}\text { Mindkét } \\
\text { vég törött }\end{array}$ & 234 & 15,50083 & 10 & 0,11484 & 16,22849 & 12 & 0,18099 & 2,16100 & 0,33950 & 0,28700 & 2,01 & 0,3658 \\
\hline & $\begin{array}{l}\text { Proximális } \\
\text { vég törött }\end{array}$ & 201 & 6,64528 & 8 & 0,57534 & 3,99746 & 6 & 0,67702 & 1,42600 & 0,49010 & 0,45100 & 1,44 & 0,4875 \\
\hline
\end{tabular}

3. táblázat. Az ép és törött pengék hosszúságadatainak illeszkedésvizsgálata. // Table 3. Broken and whole blades length data fitting.

\begin{tabular}{|c|c|c|c|c|c|c|c|c|c|c|c|c|c|}
\hline \multirow{3}{*}{\multicolumn{2}{|c|}{$\begin{array}{c}\text { Illeszkedésvizsgálat } \\
\text { Szélesség }\end{array}$}} & \multicolumn{4}{|c|}{ Lognormális } & \multicolumn{8}{|c|}{ Logaritmikus szélesség normális } \\
\hline & & \multicolumn{4}{|c|}{$x^{2}$ próba } & \multicolumn{3}{|c|}{$x^{2}$ próba } & \multicolumn{3}{|c|}{ Jarque-Bera } & \multicolumn{2}{|c|}{$\begin{array}{l}\text { D'Agostino- } \\
\text { Pearson }\end{array}$} \\
\hline & & $\#$ & $x^{2}$ & df & $\mathrm{p}$ & $x^{2}$ & df & $\mathrm{p}$ & $\mathrm{JB}$ & $\mathrm{p}$ (normal) & $\begin{array}{r}\text { p(Monte } \\
\text { Carlo) }\end{array}$ & DP & $\mathrm{p}$ \\
\hline \multicolumn{2}{|c|}{$\begin{array}{l}\text { Ép pengék (tech- } \\
\text { nológiai) }\end{array}$} & 130 & 15,7401 & 10 & 0,10732 & 6,34076 & 6 & 0,38612 & 0,2515 & 0,8818 & 0,8715 & 0,20 & 0,9038 \\
\hline \multicolumn{2}{|c|}{ Ép pengék (2:1 arány) } & 85 & 11,2947 & 8 & 0,18555 & 5,43985 & 6 & 0,48876 & 0,8570 & 0,6515 & 0,5989 & 0,80 & 0,6704 \\
\hline \multirow{6}{*}{$\begin{array}{l}\text { Törött } \\
\text { pengék }\end{array}$} & Összes & 689 & 11,8609 & 5 & 0,03674 & 15,25029 & 7 & 0,03292 & 6,7260 & 0,0346 & 0,0334 & 6,79 & 0,0335 \\
\hline & $\begin{array}{l}\text { Sima tö- } \\
\text { résfelület }\end{array}$ & 529 & 10,5763 & 5 & 0,06046 & 23,66566 & 7 & 0,00130 & 8,7370 & 0,0127 & 0,0179 & 8,88 & 0,0118 \\
\hline & $\begin{array}{l}\text { Nyelv ala- } \\
\text { kú törés }\end{array}$ & 160 & 1,08535 & 6 & 0,98217 & 9,07249 & 8 & 0,33622 & 0,2966 & 0,8622 & 0,8548 & 0,22 & 0,8955 \\
\hline & $\begin{array}{l}\text { Disztális } \\
\text { vég törött }\end{array}$ & 254 & 14,98838 & 7 & 0,03615 & 18,44419 & 7 & 0,01012 & 6,5500 & 0,0378 & 0,0398 & 7,01 & 0,0301 \\
\hline & $\begin{array}{l}\text { Mindkét } \\
\text { vég törött }\end{array}$ & 234 & 6,71152 & 7 & 0,45952 & 11,75777 & 8 & 0,16234 & 2,3860 & 0,3033 & 0,2602 & 2,15 & 0,3406 \\
\hline & $\begin{array}{l}\text { Proximális } \\
\text { vég törött }\end{array}$ & 201 & 8,35999 & 4 & 0,07925 & 11,83239 & 5 & 0,03716 & 2,7360 & 0,2546 & 0,2061 & 2,97 & 0,2260 \\
\hline
\end{tabular}

4. táblázat. Az ép és törött pengék szélességadatainak illeszkedésvizsgálata. // Table 4. Broken and whole blades width data fitting.

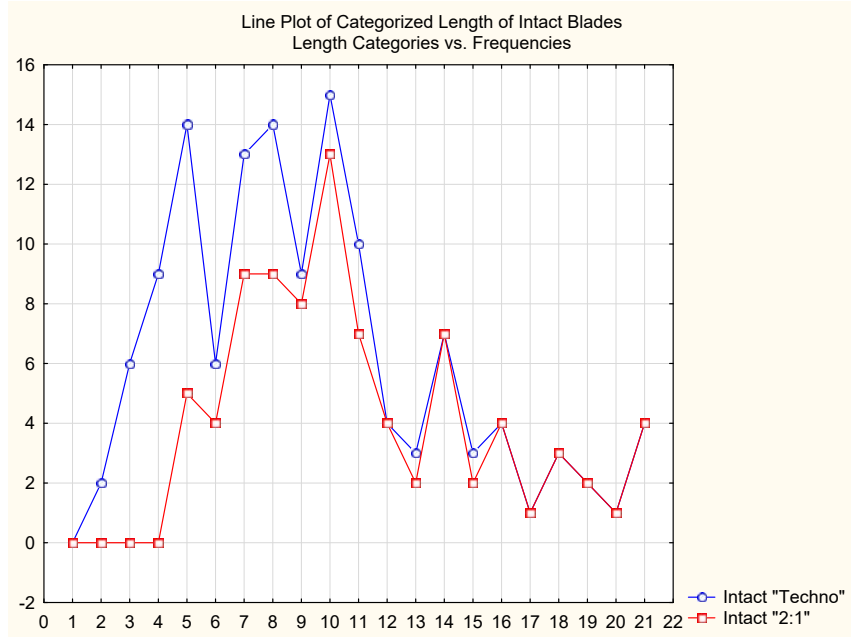

3. ábra. Az ép pengék csoportosított hosszúságadatainak eloszlásgörbéje //

Figure 3. Whole blades, length and width data.

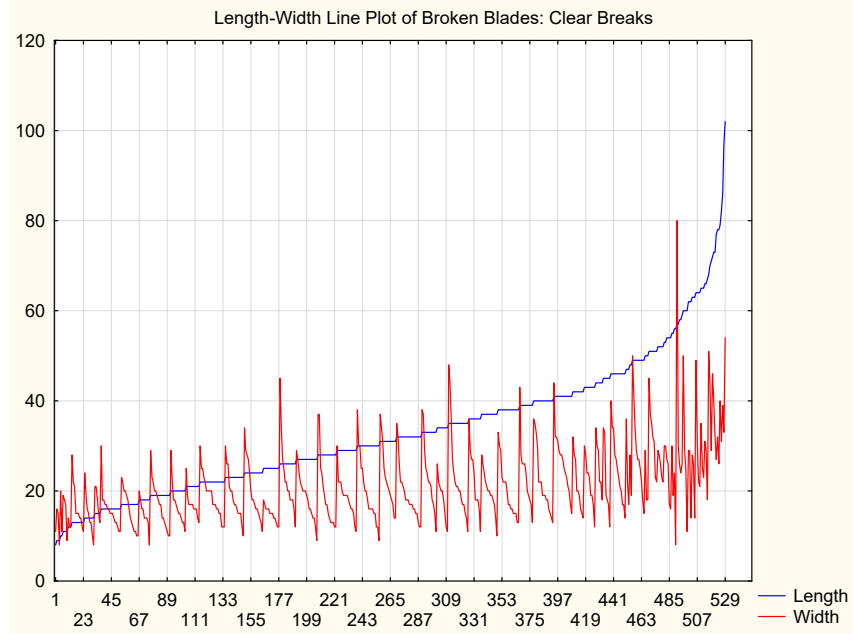

4. ábra. A sima törési felülettel rendelkező törött pengék hosszúság és szélesség adatai.

Figure 4. Whole "2:1" blades, length and width data scattergram. 


\subsubsection{Törött pengék}

A nagyszámú (689 db) vizsgálatba vont pengetöredéket (vagy törött pengét) több szempont szerint is csoportosítottuk és számoltuk ki a statisztikai jellemzőiket. Megkülönböztettük a nyelv alakú töréseket illetve a sima törésfelülettel rendelkező töréseket. A nyelv alakú törések esetén a pengetöredékeket megkülönböztettük továbbá aszerint, hogy a darab melyik vége törött, pontosabban szólva, hogy hol található a törési felületen a nyelv. A törések jelentős része nyelv alakú törés (cassure en languette), amelyet egyértelműen pattintási hibának tekintünk (Inizan et al. 1999: 35, Fig. 6, 37, Fig. 7). Akkor keletkeznek, ha a merőlegesen induló másodlagos hullám elkanyarodik, még mielőtt elérné a darab másik felszínét, s egy ideig azzal párhuzamosan haladva végül kifut a felszínre. A törési felület hirtelen ívelődéssel egy nyelvre emlékeztető nyúlványba megy át. A keletkezett nyelv lehet alsó vagy felső állású, aszerint hogy a törési felületnek a hátlap vagy az előlap felöli oldalán helyezkedik el (Holló et al. 2004: 71, 7. kép, 72).

A sima törésfelületű törések esetében a törésfelület merőleges a leválasztás tengelyére és a penge hátlapjára (Inizan et al. 1999, 34). Eltekintettünk a törés tényleges okainak a vizsgálatától, de nagy határozottsággal feltételezhető hogy részben itt is a debitázs közben keletkező törésről lehet szó. Amikor a szándékos törés céljából egy erős ütést mérünk a penge valamelyik lapjára, akkor a törésfelület merőleges a leválasztás tengelyére és a penge lapjaira. Az ütés nyomai azonban megtalálhatóak a darab felületén (a borda sérülése vagy elvetélt ütési kúp) vagy pedig a törési felületen (ütközési pont, ütési kúp). A nyelv alakú törés analógiájára „ajak alakú törés” lehet a neve annak a törésnek, amikor a törésfelület egyik peremén egy kiemelkedő keskeny párkány húzódik (Deller, Ellis 2001: 272; Weitzel, Colombo 2006: 24). Ilyen törésfelület keletkezhet a hajlítás általi szándékos törés esetén, de keletkezhet véletlenszerüen is, taposás következtében. Az ék alakú törésvonalak ugyancsak mind a szándékos hajlítás mind a taposás során előfordulhatnak (Kofidou 2009: 112). Miután sem a pengék sem pedig az eszközök esetében taposás folytán keletkező gyakori sérülés (élsérülés, csorbulás ) nem volt diagnosztizálható, így a taposás, mint töréseknek egy lehetséges forrása nagy valószínűséggel kizárható az okok közül.

\subsubsection{Sima vs. nyelv alakú törési felülettel rendelkezó pengék}

A vizsgált törött pengék közül a sima törésfelülettel rendelkező töréseket száma $529 \mathrm{db}$ (76,78 \%), a nyelv alakú töréseké $160 \mathrm{db}$ (23,22 \%). Az 1. táblázatban látható hogy az ép pengékhez viszonyítva a törött pengék mindkét kategóriájának jelentősen, mintegy 15-16 mm-el kisebb az átlagos hosszúsága és jóval kisebb a hosszúságadatok szórása is. Az ép és törött pengék átlagos szélessége ugyanakkor gyakorlatilag szinte megegyezó és a törött pengék esetében a szórás is csupán jelentéktelen mértékben magasabb. Mind a hosszúságadatok mind a szélességadatok tekintetében igen csekély az eltérés a törött pengék két kategória adatai között, a nyelv alakú törési felülettel rendelkező pengék átlagosan 0,84 mm-el hoszszabbak és 0,71 mm-el szélesebbek. Ugyanez a hasonlóság vonatkozik a szórásokra is, a különbség mindkét adat esetében kisebb, mint $1 \%$.
A 4. és 5. ábrán látható a sima illetve nyelv alakú törési felülettel rendelkező törött pengék hosszúság- és szélességadatai. Egy összevont ábra a mintaelemek számának jelentős különbsége miatt nem lenne értelmezhető, a közvetlen öszszehasonlítás még így sem könnyü. Ami szembetûnő, hogy a sima törési felülettel rendelkező törött pengék esetén a diagram harmonikusabb lefutású, az ugrások amplitúdója kisebb. Csupán a hosszabb pengék ( $\mathrm{L}>60 \mathrm{~mm}$ ) esetén lesz a szélesség rendszertelenebb. A hosszúság és szélesség közötti korreláció mindkét kategória esetén alacsony, sima törésfelületű törések esetén r=0,51953, nyelv alakú törések esetén $r=0,47673$.

Ha a sima törésfelületü töréseknek legalábbis egy része szándékos törés lenne, akkor vélhetően a méretadatoknak egyfajta standardizációra való törekvést kellene mutatniuk. A nyelv alakú törések mint tudjuk pattintási hibák. Mivel nagy általánosságban megállapítható hogy a két törési kategória közötti statisztikai különbségek meglehetösen kicsik, így a szándékos törések megléte ennek alapján nem valószínü.

Némi különbséget látszik a két töréskategória között a 3. táblázat alapján az eloszlásban, a „sima” törések esetén a lornormalitásra a $\chi 2$ próba eredménye $(\mathrm{p}=0.04126)$ nem éri el az $\alpha=0,05$ szignifikanciaszintet sem; a nyelv alakú töréseknél ez az érték magasabb ( $\mathrm{p}=0,16276)$. A „sima” törések logaritmikus hosszúságadatai nem is normálisak, míg a nyelv alakú törések esetén valamennyi teszt normális eloszlást eredményez. Jelentős különbség van viszont a szélességadatok esetében, itt a „sima” törések eloszlása éppen hogy meghaladja az $\alpha=0,05$ szignifikanciaszintet $(\mathrm{p}=0.06046)$, a nyelv alakú töréseké határozottan lognormális, magas valószínűséggel $(\mathrm{p}=0,98217)$.

A „sima” törések logaritmikus szélességadatai nem is normálisak eloszlásúak, míg a nyelv alakú törések esetén különösen a csúcsosság és ferdeség vizsgálatán alapuló tesztek magas valószínúségi értékkel normális eloszlást mutatnak. A „sima” törések az 1. és 2. táblázatok adatai alapján egy viszonylag erősen jobbra ferde eloszlást mutatnak, anélkül, hogy valamely hasonló eloszlásra illeszkednének.

\subsubsection{Retusált pengék}

A következőkben megvizsgáljuk az ép illetve törött retusált pengék metrikus adatait illetve eloszlásgörbéit. A törött pengéket megkülönböztetjük továbbá a törés helyzete alapján.

\subsubsection{1. Ép retusált pengék}

Az 1. és 9. táblázatban látható, hogy az ép retusált pengék átlaghosszúsága (57,62 mm) 7,86 mm-el nagyobb mint az ép „technológiai” pengék átlaghosszúsága (49,76 mm), ugyanakkor 0,84 mm-el, tehát alig valamivel kisebb mint az ép „2:1” pengék átlaghosszúsága $(58,46 \mathrm{~mm})$. Igen hasonlóak a szórásadatok is, szúkebb viszont a hosszúságintervallum amelyben a retusált pengék mozognak. A szélességadatok esetén a retusált pengék átlagszélessége valamivel (2,46 illetve 3,86 mm-el) nagyobb mind az ép „technológiai” pengék, mind az ép „2:1” pengék átlagszélességénél. 
A metrikus adatok átlagértékei alapján az „idealizált” méretkategória 57,62×24,58 mm, az L/W arány 2,34. A pengék átlagos vastagsága 9,77 mm. A retusált pengék tehát nem különösebben nyújtottak, inkább masszív, vaskos, széles darabok.

A 10. táblázatban, az illeszkedési vizsgálatok alapján látható, hogy míg az összes retusált penge eloszlási görbéje határozottan lognormális, az ép retusált pengék esetében a p valószínüségi érték eléggé alacsony $(0,162)$, és a logaritmikus adatok sem mutatnak erős normális eloszlást. Érdekes ugyanakkor, hogy a szélesség adatok eloszlása erősen lognormális és ugyanez mondató el a logaritmikus szélesség normalitására is. Különösen a csúcsosság és ferdeség alapján végzett Jarquebera és D’Agostino-Pearson vizsgálatok esetében.

A 3. ábrán látható az ép retusálatlan pengék csoportosított hosszúságadatainak eloszlásgörbéje. Az alábbi 9. ábrán egy diagramon ábrázoljuk az ép retusált pengékkel. A retusált pengék eloszlásgörbéje sokkal jobban illeszkedik az ép „,techno" pengékhez, amit a viszonylag magas korrelációs érték $(\mathrm{r}=0,648652)$ is igazol. A retusált pengéknek az ép „2:1” pengékhez való korrelációs kapcsolata igen alacsony $(\mathrm{r}=0,226360)$. A jelenség egy életszerú magyarázata, hogy a 16-45 mm hoszszúságintervallumban éppen azért olyan kevés a retusálatlan ép „2:1” pengék száma mert retusálták őket. A 3. ábra kapcsán már megemlítettük, hogy az ép pengék esetében tulajdonképpen bimodális eloszlásgörbével van dolgunk. A retusált pengék esetén ugyanúgy jelen van ez a bimodalitás, viszonylag jelentősebb a 71-85 mm hosszúságú ép retusált penge is.

\subsubsection{Törött retusált pengék}

A 130 db törött retusált penge közül 49 darabnak (37,7 \%) a disztális vége, 43 darabnak mindkét vége (33,08 \%), 38 darabnak a proximális vége (29,23\%) törött. A törések túlnyomó része sima törési felületü törés, a disztális illetve proximális végükön törött pengék közül 8 illetve 7 darabon nyelv alakú törés látható. A nyelv alakú törés aránya viszonylag magas (18 $\mathrm{db}$ ) a mindkét végükön törött pengék esetében, ami a $43 \mathrm{db}$ 41,86 \%-a. Viszonylag jelentős az átlagos hosszúság különbsége. A legrövidebbek a mindkét végükön törött pengék (30,63 $\mathrm{mm})$, hosszabbak a disztális végükön törött (37,20 mm), a leghosszabbak a proximális végükön törött (48,03 \%) pengék. Ez utóbbiak esetében a legszélesebb a pengék hosszúságintervalluma (13-120 mm), így a legmagasabb a szórás értéke is.

A 10. ábrán egy diagramon ábrázoltuk a törött retusált pengéket. Az eloszlásgörbék ugyan viszonylag jól szemléltetik a hosszúságra vonatkozó fenti megállapításokat, összességükben azonban igen szabálytalan, „zaklatott” benyomást keltenek. Az ép retusált pengék esetében egy tendencia látszik érvényesülni, nyilvánvalóan funkcionális megfontolások alapján két hosszúság-kategóriát részesítettek előnyben. Itt viszont látszólag spontán módon kiválasztott és tovább megmunkált, retusált darabokkal találkozunk.

\subsubsection{Eszközök}

A 11. ábra egy diagramon több adatsort is ábrázol. A törött pengéken belül szétválasztottuk azokat, amelyeken nyelv alakú törések láthatóak, és azokat, amelyek sima törésfelülettel rendelkeznek. Amint már utaltunk rá, ennek a szétválasztásnak azért van értelme, mert a nyelv alakú törések tipikusan a penge leválasztása során keletkeznek, vagyis a debitázs során keletkezett véletlen erőhatás töri el a leendő szupportot. Az eszközök közül pedig szétválasztottuk azokat amelyeket ép szupporton, és azokat amelyeket törött szupporton készítettek. Itt az első esetben a retusált pengéket is tartalmazó 236 darabos eszközkészlet adatai, a második esetben a retusált pengék nélküli 106 darab eszköz adatai szerepelnek.

Az adatokat abból a célból, hogy egy ábrán értelmezhetóek legyenek, a korábbiakhoz hasonlóan 5 mm-es hosszúsági mérettartományokba csoportosítottuk, ezúttal azonban nem abszolút, hanem százalékos formában kezeltük őket. Az $X$ tengelyen találhatóak tehát a mérettartományok, az $Y$ tengelyen pedig, hogy az adott kategória mekkora százalékban képviselteti magát. Ily módon ha lenne összefüggés például a nem nyelv alakú törést szenvedet pengék és az eszközök bármely kategóriája között, az világosan kirajzolódna.

Ilyen kapcsolatot azonban nem tapasztalhatunk. Három eloszlásgörbe, a pengék nyelv alakú illetve sima törésekkel, és a törött szupportú eszközök szinte teljesen együtt futnak. Az ép szupportú eszközök vonala azonban radikálisan eltér a másik háromtól, más mérettartományok dominálnak, és sokkal nagyobb ugrások tapasztalhatóak az egyes csoportok között. Kifejezetten feltûnő a 8. hosszúságkategória, a 41-45 mm hosszú eszközök hirtelen kiugró értéke. Figyelemre méltó az eloszlásgörbe bimodális jellege is, az ép eszközök esetében pengevakarók és retusált pengék folytán a nagyobb méretkategóriák is viszonylag nagyobb arányban képviseltetik magukat.

\subsubsection{A pengék szélességadatai}

A pengék szélességadatait 8-55 mm között, 16 darab egyenlő közű, 3 mm szélességú intervallum alapján gyakorisági csoportokba soroltuk. Ha az ép pengéket vetjük össze a törött pengékkel (12. ábra) tapasztalhatjuk, hogy az egyes szélességkategóriák hasonló arányban szerepelnek, vagyis adott szélességü pengék ugyanolyan gyakran találhatóak meg törött, mint ép állapotban. Ezt bizonyítják a magas korrelációs értékek is: az ép „techno” pengék és az ép „2:1” pengék között r=0,981578, az ép „techno” pengék és a törött pengék között $r=0,923993$, az ép „2:1" pengék és a törött pengék között pedig $\mathrm{r}=0,939106$. A leggyakoribbak a 3-5. szélességkategóriába eső, 16-22 mm széles pengék. A magas korrelációs értékek ismételten egyfajta standardizált penge-debitázs meglétére utalnak.

\section{6. Összefoglalás}

A pengék előállítása során gyakran jelentkeztek törések és egyéb pattintási hibák. A töréseknek egyáltalán nem tulajdonítottak különleges jelentőséget, azonban az egyéb pattintási hibákat szenvedett darabokat igyekeztek nem felhasználni a továbbiakban. A metrikus adatok vizsgálatánál, az eszköztípusok és a különféle törött pengék hosszadatainak összehasonlításából valószínüsíthető az is, hogy a törések minden bizonnyal nem szándékosan keletkeztek. A 7. és 8. ábrák, a sima törési felületű illetve a nyelv alakú törések kategorizált 


\begin{tabular}{|c|c|c|c|c|c|c|c|c|c|c|c|c|}
\hline $\begin{array}{l}\text { Sima tö- } \\
\text { résfelület }\end{array}$ & $\#$ & $\%$ & & Átlag & Szórás & $\begin{array}{r}\text { Var. } \\
\text { Koeff. \% }\end{array}$ & $\begin{array}{l}\text { Mini- } \\
\text { mum }\end{array}$ & Medián & Módusz & $\begin{array}{l}\text { Maxi- } \\
\text { mum }\end{array}$ & $\begin{array}{r}\text { Csúcsos- } \\
\text { ság }\end{array}$ & Ferdeség \\
\hline \multirow{2}{*}{$\begin{array}{l}\text { Disztális } \\
\text { vég törött }\end{array}$} & \multirow{2}{*}{202} & \multirow{2}{*}{38,19} & Hosszúság & 33,69 & 14,27 & 42,34 & 8 & 32,00 & 32,00 & 97 & 1,51803 & 0,89245 \\
\hline & & & Szélesség & 20,56 & 7,46 & 36,29 & 8 & 18,00 & 18,00 & 50 & 2,83553 & 1,45196 \\
\hline \multirow{2}{*}{$\begin{array}{l}\text { Mindkét } \\
\text { vég törött }\end{array}$} & \multirow{2}{*}{165} & \multirow{2}{*}{31,19} & Hosszúság & 29,03 & 13,34 & 45,95 & 9 & 25,00 & 22,00 & 73 & 0,74164 & 1,01290 \\
\hline & & & Szélesség & 20,56 & 8,03 & 39,06 & 8 & 19,00 & 20,00 & 48 & 0,77931 & 0,97579 \\
\hline \multirow{2}{*}{$\begin{array}{l}\text { Proximális } \\
\text { vég törött }\end{array}$} & \multirow{2}{*}{162} & \multirow{2}{*}{30,62} & Hosszúság & 37,06 & 15,46 & 41,73 & 10 & 35,00 & 27,00 & 102 & 2,34403 & 1,30164 \\
\hline & & & Szélesség & 22,03 & 9,58 & 43,47 & 9 & 19,50 & 15,00 & 80 & 8,26565 & 2,110918 \\
\hline
\end{tabular}

5. táblázat. A sima törési felületű törött pengék metrikus adatainak statisztikai jellemzői. // Table 5. Blades with clean break surfaces, metric statistics.

\begin{tabular}{|c|c|c|c|c|c|c|c|c|c|c|c|c|}
\hline $\begin{array}{l}\text { Nyelv alakú } \\
\text { törésfelület }\end{array}$ & $\#$ & $\%$ & & Átlag & Szórás & $\begin{array}{r}\text { Var. } \\
\text { Koeff. \% }\end{array}$ & $\begin{array}{l}\text { Mini- } \\
\text { mum }\end{array}$ & Medián & Módusz & $\begin{array}{l}\text { Maxi- } \\
\text { mum }\end{array}$ & $\begin{array}{r}\text { Csúcsos- } \\
\text { ság }\end{array}$ & Ferdeség \\
\hline \multirow{2}{*}{$\begin{array}{l}\text { Disztális } \\
\text { vég törött }\end{array}$} & \multirow{2}{*}{52} & \multirow{2}{*}{32,50} & Hosszúság & 30,90 & 13,91 & 45,01 & 13 & 28,00 & 20,00 & 75 & 1,05652 & 1,12977 \\
\hline & & & Szélesség & 21,85 & 7,82 & 35,81 & 12 & 20,00 & 22,00 & 46 & 2,05704 & 1,41014 \\
\hline \multirow{2}{*}{$\begin{array}{l}\text { Mindkét } \\
\text { vég törött }\end{array}$} & \multirow{2}{*}{69} & \multirow{2}{*}{43,13} & Hosszúság & 33,09 & 14,78 & 44,66 & 8 & 32,00 & 20,00 & 82 & 0,75742 & 0,76632 \\
\hline & & & Szélesség & 21,70 & 6,89 & 31,78 & 11 & 21,00 & 18,00 & 39 & $-0,12942$ & 0,68054 \\
\hline \multirow{2}{*}{$\begin{array}{l}\text { Proximális } \\
\text { vég törött }\end{array}$} & \multirow{2}{*}{39} & \multirow{2}{*}{24,38} & Hosszúság & 40,79 & 16,30 & 39,95 & 12 & 38,00 & 34,00 & 84 & 0,11646 & 0,49880 \\
\hline & & & Szélesség & 21,54 & 7,82 & 36,32 & 9 & 21,00 & 17,00 & 40 & 0,10279 & 0,48571 \\
\hline
\end{tabular}

6. táblázat. A nyelv alakú törések metrikus adatainak statisztikai jellemzői. // Table 6. Blades with languettes, metric statistics.

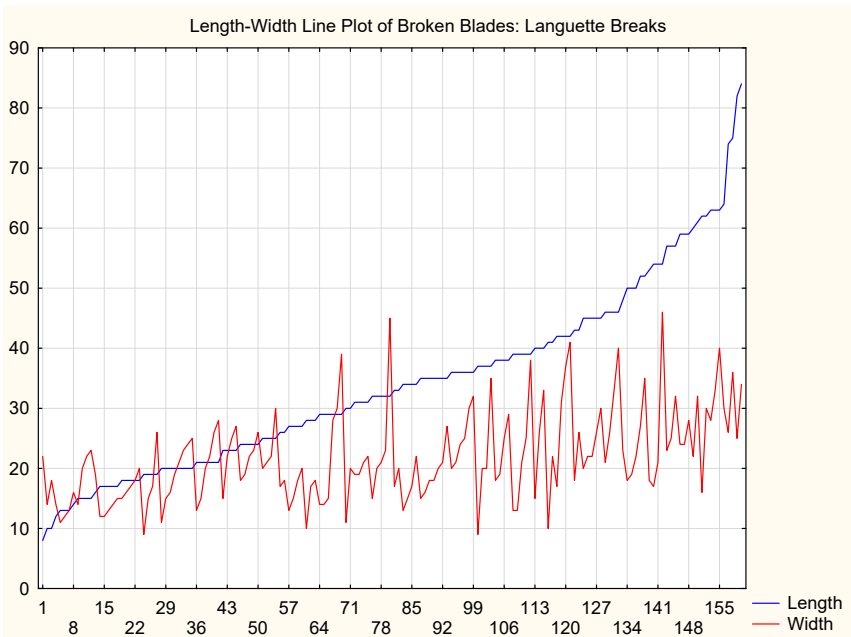

5. ábra. A nyelv alakú törési felülettel rendelkező törött pengék hoszszúság és szélesség adatai // Figure 5. Blades with languette break surfaces; length and width data.

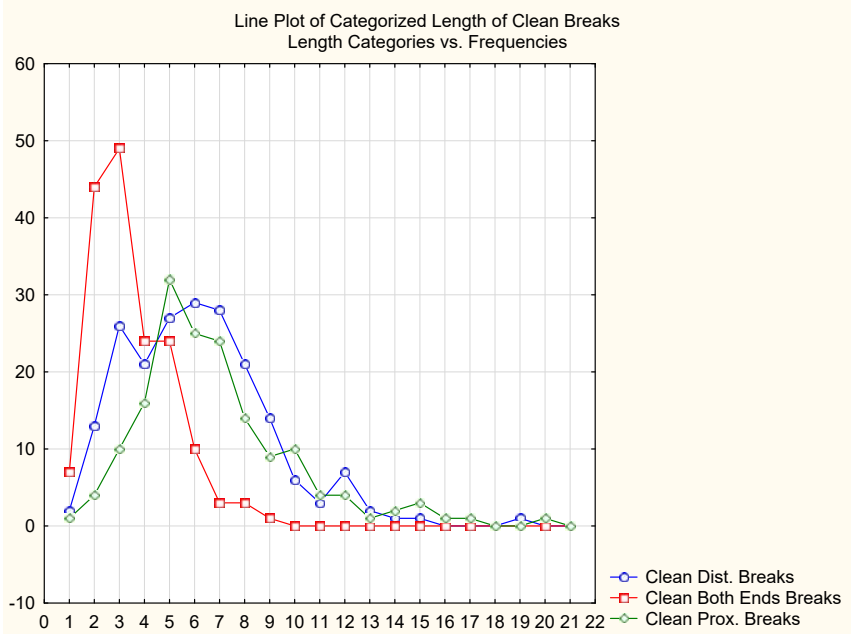

7. ábra. A sima törési felülettel rendelkező törött pengék hosszúság és szélesség adatai // Figure 7. Blades with clean break surfaces; length and width data.

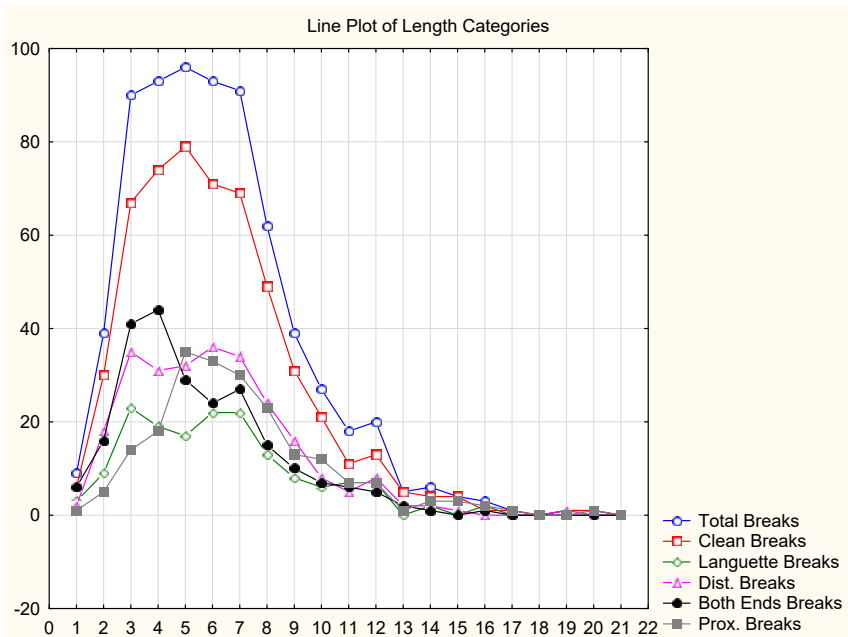

6. ábra. A törött pengék kategorizált hosszúságadatainak eloszlásgörbéi. // Figure 6. Broken blades, length distribution curves. (Total Breaks=valamennyi törött penge, Clean Breaks="sima" törések; Languette Breaks=nyelv alakú törések, Dist. Breaks=disztális törések, Both Ends Breaks=mindkét vég törött, Prox. Breaks=proximális törések)

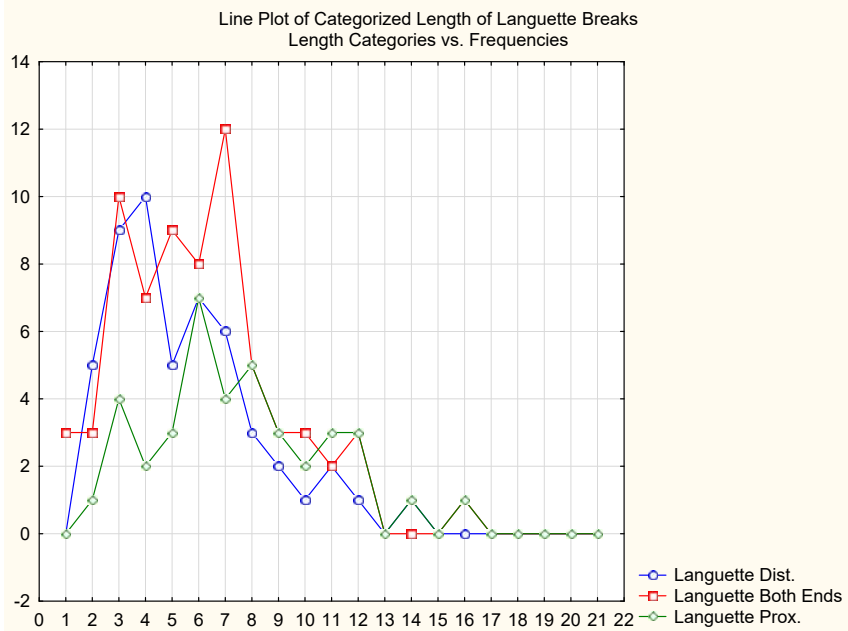

8. ábra. A nyelv alakú törések kategorizált hosszúságadatainak eloszlásgörbéi. // Figure 8. Languettes, length distribution curves. 


\begin{tabular}{|c|c|c|c|c|c|c|c|c|c|c|c|c|c|}
\hline \multirow{3}{*}{\multicolumn{2}{|c|}{$\begin{array}{l}\text { Illeszkedésvizsgálat } \\
\text { Hosszúság }\end{array}$}} & \multirow{2}{*}{\multicolumn{4}{|c|}{$\begin{array}{l}\text { Lognormális } \\
\text { x2 próba }\end{array}$}} & \multicolumn{8}{|c|}{ Logaritmikus hosszúság normális } \\
\hline & & & & & & \multicolumn{3}{|c|}{$x^{2}$ próba } & \multicolumn{3}{|c|}{ Jarque-Bera } & \multicolumn{2}{|c|}{$\begin{array}{l}\text { D'Agostino- } \\
\text { Pearson }\end{array}$} \\
\hline & & $\#$ & $x^{2}$ & df & $\mathrm{p}$ & $x^{2}$ & df & $\mathrm{p}$ & JB & $\mathrm{p}$ (normal) & $\begin{array}{r}\mathrm{p} \text { (Monte } \\
\text { Carlo) }\end{array}$ & DP & p \\
\hline \multirow{3}{*}{$\begin{array}{l}\text { Sima } \\
\text { törés- } \\
\text { felület }\end{array}$} & $\begin{array}{l}\text { Disztális } \\
\text { vég törött }\end{array}$ & 202 & 15,55874 & 8 & 0,04915 & 21,73663 & 9 & 0,00975 & 4,2710 & 0,1182 & 0,0926 & 4,36 & 0,1129 \\
\hline & $\begin{array}{l}\text { Mindkét } \\
\text { vég törött }\end{array}$ & 165 & 7,73432 & 9 & 0,56113 & 14,49048 & 11 & 0,20703 & 1,4910 & 0,4744 & 0,4252 & 1,39 & 0,4993 \\
\hline & $\begin{array}{l}\text { Proximális } \\
\text { vég törött }\end{array}$ & 162 & 8,06842 & 7 & 0,32660 & 13,20085 & 8 & 0,10512 & 1,1810 & 0,5541 & 0,5078 & 1,51 & 0,4688 \\
\hline \multirow{3}{*}{$\begin{array}{l}\text { Nyelv } \\
\text { alakú } \\
\text { törés }\end{array}$} & $\begin{array}{l}\text { Disztális } \\
\text { vég törött }\end{array}$ & 52 & 3,32204 & 5 & 0,65047 & 3,67610 & 5 & 0,59692 & 1,4770 & 0,4779 & 0,3505 & 1,46 & 0,4824 \\
\hline & $\begin{array}{l}\text { Mindkét } \\
\text { vég törött }\end{array}$ & 69 & 6,73951 & 6 & 0,34561 & 3,32654 & 6 & 0,76689 & 2,6770 & 0,2622 & 0,1558 & 2,97 & 0,2264 \\
\hline & $\begin{array}{l}\text { Proximális } \\
\text { vég törött }\end{array}$ & 39 & 0,69695 & 2 & 0,70576 & 1,53308 & 2 & 0,46462 & 1,9560 & 0,3760 & 0,2083 & 2,31 & 0,3148 \\
\hline
\end{tabular}

7. táblázat. A sima törési felületű és nyelv alakú törések hosszúságadatainak illeszkedésvizsgálata. // Table 7. Blades with clean and languette breaks, length data fitting

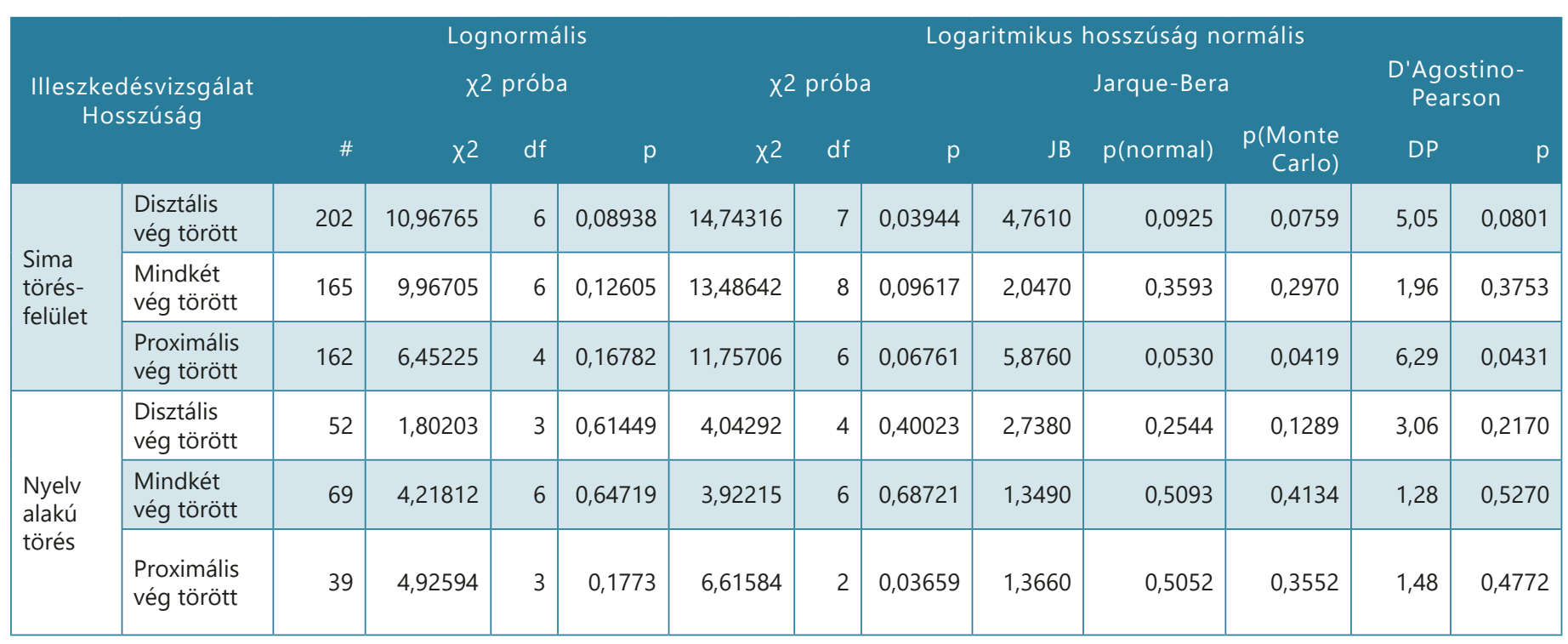

8. táblázat. A sima törési felületű és nyelv alakú törések szélességadatainak illeszkedésvizsgálata. // Table 8. Blades with clean and languette breaks, width data fitting.

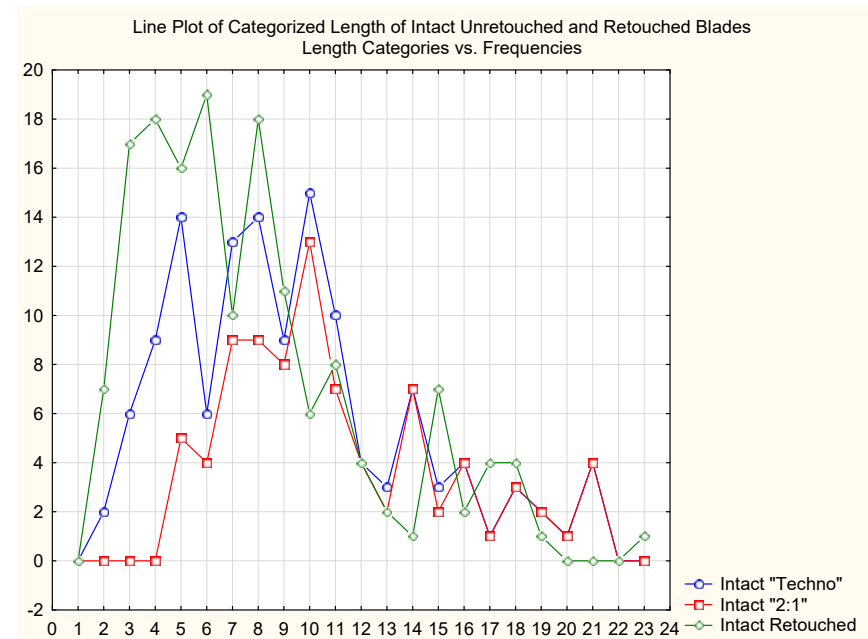

9. ábra. Az ép retusálatlan és retusált pengék csoportosított hosszúságadatainak eloszlásgörbéje. // Figure 9. Whole blades and retouched blades, distribution curve for categorized length data.

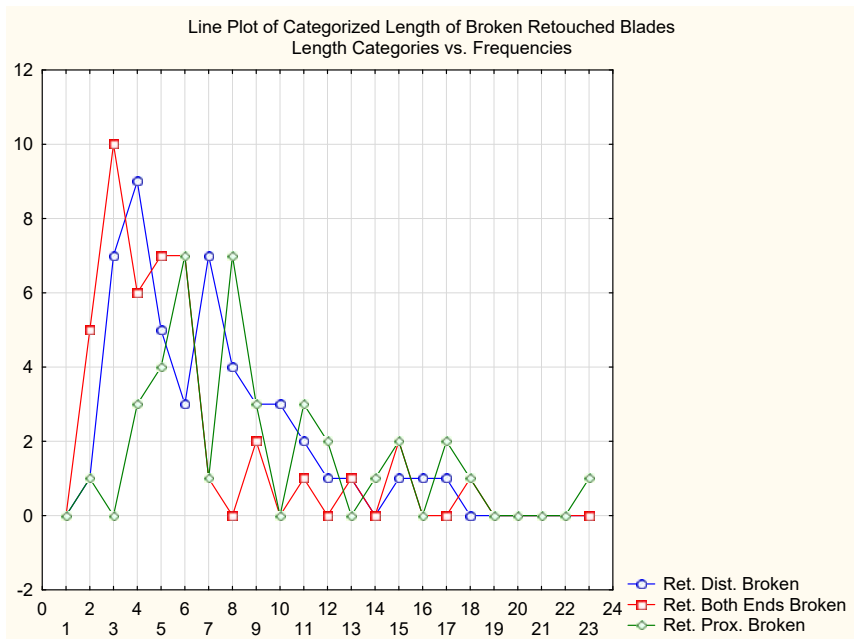

10. ábra. Törött retusált pengék csoportosított hosszúságadatainak eloszlásgörbéje. // Figure 10. Broken retouched blades, distribution curve for categorized length data. 


\begin{tabular}{|c|c|c|c|c|c|c|c|c|c|c|c|}
\hline Sima törésfelület & $\#$ & & Átlag & Szórás & $\begin{array}{r}\text { Var. } \\
\text { Koeff. \% }\end{array}$ & $\begin{array}{l}\text { Mini- } \\
\text { mum }\end{array}$ & Medián & Módusz & $\begin{array}{l}\text { Maxi- } \\
\text { mum }\end{array}$ & $\begin{array}{r}\text { Csúcsos- } \\
\text { ság }\end{array}$ & Ferdeség \\
\hline \multirow[t]{2}{*}{ Összes } & \multirow[t]{2}{*}{156} & Hosszúság & 41,49 & 22,02 & 53,16 & 11 & 37,00 & $\begin{array}{l}\text { több- } \\
\text { szörös }\end{array}$ & 120 & 0,73564 & 1,07287 \\
\hline & & Szélesség & 22,06 & 8,53 & 38,69 & 9 & 22,00 & 14,00 & 65 & 3,59516 & 1,39241 \\
\hline \multirow{2}{*}{ Ép } & \multirow{2}{*}{26} & Hosszúság & 57,62 & 20,50 & 35,57 & 33 & 50,50 & 42,00 & 99 & $-0,61563$ & 0,85413 \\
\hline & & Szélesség & 24,58 & 8,24 & 33,52 & 13 & 23,50 & 23,00 & 46 & 0,65956 & 0,84351 \\
\hline \multirow{2}{*}{ Disztális vég törött } & \multirow{2}{*}{49} & Hosszúság & 37,20 & 18,18 & 48,86 & 11 & 35,00 & 25,00 & 87 & 0,87505 & 1,08311 \\
\hline & & Szélesség & 21,47 & 9,93 & 46,24 & 9 & 20,00 & 14,00 & 65 & 6,71932 & 2,05174 \\
\hline \multirow{2}{*}{ Mindkét vég törött } & \multirow[t]{2}{*}{43} & Hosszúság & 30,63 & 18,76 & 61,24 & 12 & 26,00 & 17,00 & 93 & 3,03525 & 1,83000 \\
\hline & & Szélesség & 19,77 & 6,55 & 33,11 & 11 & 19,00 & 16,00 & 42 & 2,182154 & 1,233738 \\
\hline \multirow{2}{*}{ Proximális vég törött } & \multirow[t]{2}{*}{38} & Hosszúság & 48,03 & 23,06 & 48,02 & 13 & 42,00 & 35,00 & 120 & 1,41129 & 1,20444 \\
\hline & & Szélesség & 23,68 & 8,31 & 35,07 & 11 & 24,00 & 26,00 & 43 & $-0,28778$ & 0,52890 \\
\hline
\end{tabular}

9. táblázat. A retusált pengék hosszúság- és szélességadatainak statisztikai jellemzői // Table 9. Retouched blades, length and width statistics.

\begin{tabular}{|c|c|c|c|c|c|c|c|c|c|c|c|c|}
\hline \multirow{3}{*}{\multicolumn{2}{|c|}{ Illeszkedésvizsgálat }} & \multirow{2}{*}{\multicolumn{3}{|c|}{$\begin{array}{l}\text { Lognormális } \\
\text { x2 próba }\end{array}$}} & \multicolumn{8}{|c|}{ Logaritmikus hosszúság normális } \\
\hline & & & & & \multicolumn{3}{|c|}{ x2 próba } & \multicolumn{3}{|c|}{ Jarque-Bera } & \multicolumn{2}{|c|}{$\begin{array}{l}\text { D'Agostino- } \\
\text { Pearson }\end{array}$} \\
\hline & & $x^{2}$ & df & $\mathrm{p}$ & $x^{2}$ & df & $\mathrm{p}$ & JB & $\mathrm{p}$ (normal) & $\begin{array}{r}\mathrm{p} \text { (Monte } \\
\text { Carlo) }\end{array}$ & DP & $\mathrm{p}$ \\
\hline \multirow{2}{*}{$\begin{array}{l}\text { Összes } \\
\text { (156) }\end{array}$} & Hosszúság & 6,94814 & 8 & 0,54224 & 8,71216 & 10 & 0,55962 & 2,39100 & 0,30250 & 0,23910 & 2,31 & 0,31500 \\
\hline & Szélesség & 14,94219 & 4 & 0,00482 & 8,67177 & 7 & 0,27709 & 1,168000 & 0,557800 & 0,525100 & 1,13 & 0,56920 \\
\hline \multirow{2}{*}{ Ép (26) } & Hosszúság & 1,95549 & 1 & 0,16200 & 2,26387 & 1 & 0,13242 & 2,02800 & 0,36280 & 0,14660 & 2,34 & 0,31100 \\
\hline & Szélesség & 0,35455 & 1 & 0,55155 & 5,24923 & 1 & 0,02196 & 0,312700 & 0,855300 & 0,844700 & 0,19 & 0,90920 \\
\hline \multirow{2}{*}{$\begin{array}{l}\text { Disztális } \\
\text { vég tö- } \\
\text { rött (49) }\end{array}$} & Hosszúság & 6,10329 & 4 & 0,19157 & 3,99959 & 4 & 0,40606 & 0,57350 & 0,75070 & 0,70570 & 0,47 & 0,79220 \\
\hline & Szélesség & 2,04810 & 2 & 0,35914 & 3,87863 & 4 & 0,42268 & 1,250000 & 0,535300 & 0,413400 & 1,70 & 0,42780 \\
\hline \multirow{2}{*}{$\begin{array}{l}\text { Mindkét } \\
\text { vég tö- } \\
\text { rött (43) }\end{array}$} & Hosszúság & 2,37653 & 3 & 0,49802 & 5,42231 & 3 & 0,14336 & 3,64500 & 0,16170 & 0,07900 & 4,20 & 0,12260 \\
\hline & Szélesség & 10,70095 & 3 & 0,01346 & 5,73280 & 3 & 0,12536 & 1,179000 & 0,554700 & 0,440600 & 1,21 & 0,54510 \\
\hline \multirow{2}{*}{$\begin{array}{l}\text { Proximális } \\
\text { vég tö- } \\
\text { rött (38) }\end{array}$} & Hosszúság & 2,03183 & 2 & 0,36207 & 1,28982 & 2 & 0,52471 & 0,01157 & 0,99420 & 0,99440 & 0,12 & 0,94200 \\
\hline & Szélesség & 7,46634 & 3 & 0,05843 & 4,04228 & 2 & 0,13250 & 1,243000 & 0,537200 & 0,407800 & 1,25 & 0,53630 \\
\hline
\end{tabular}

10. táblázat. A retusált pengék hosszúság- és szélességadatainak illeszkedésvizsgálata. //

Table 10. Retouched blades, width and length data fitting.

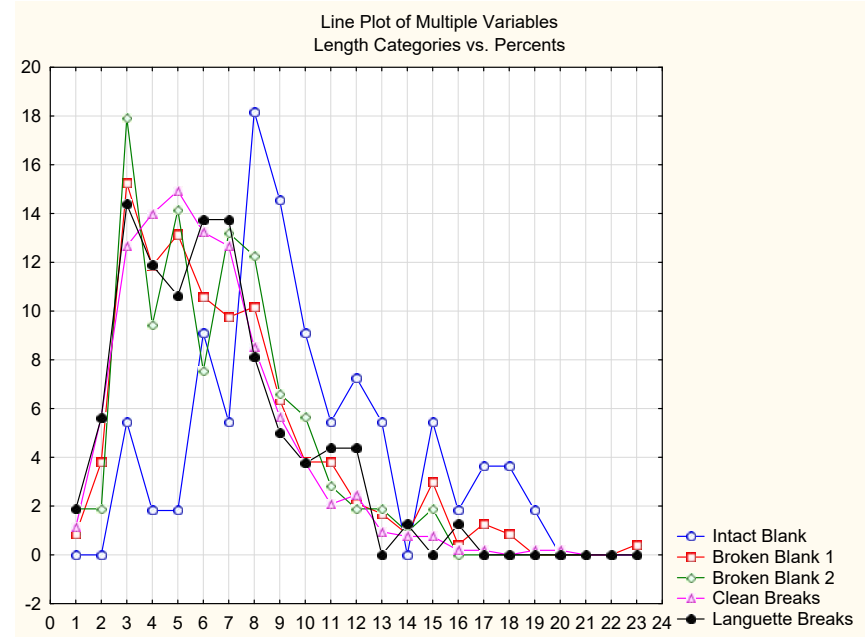

11. ábra. Az ép és törött szupporton készült eszközök és retusált pengék, a nyelv alakú és sima törések csoportosított hosszúságadatainak eloszlásgörbéje. // Figure 11. Retouched blades and tools made on whole and broken blades, distribution curve for categorized length data. (Intact Blank=ép szupport, Broken Blank=törött szupport; Clean Breaks="sima" törések; Languette Breaks=nyelv alakú törések)

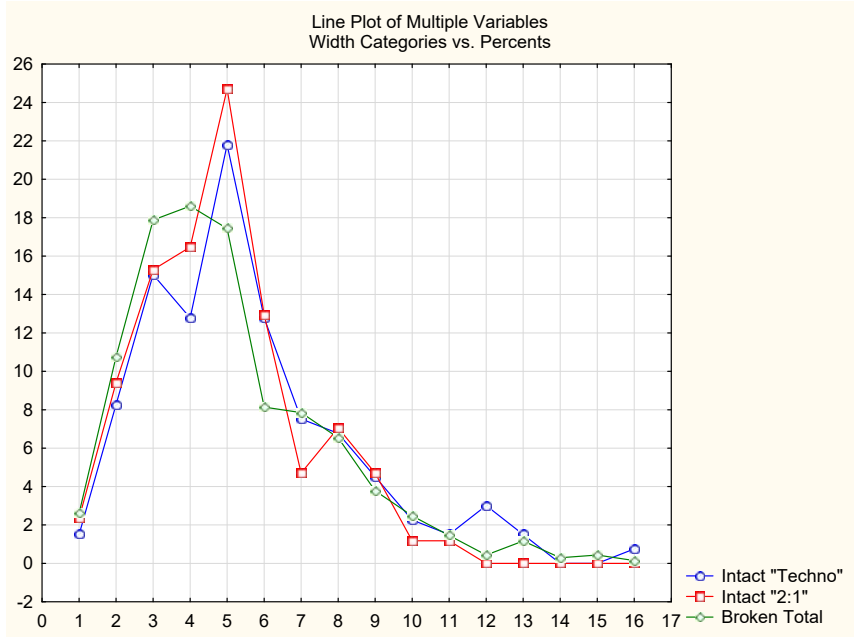

12. ábra. Az ép és törött pengék csoportosított szélességadatainak eloszlásgörbéje. // Figure 12. Broken and whole blades, distribution curve for categorized width data. (Intact "Techno"=ép "techno" pengék, Intact "2:1"=ép "2:1" pengék; Broken Total= törött pengék) 
hosszúságadatainak eloszlásgörbéi alapján egyértelműen látható, hogy nem sikerült olyan mérettartományt kimutatni, amelyet a törött pengék esetében következetesen preferáltak volna. Márpedig egy ilyen mérettartomány jelezné, hogy a különböző hosszúságú pengetöredékekból bizonyos hosszúságú darabokat válogattak ki.

A hosszúságadatokoknál tapasztalható lognormális eloszlások azonban már eleve sugallták a törések véletlenszerü, nem mesterséges voltát.

A lelőhely Simán Katalin megállapítása szerint egy ideiglenes vadásztanya lehetett, és amíg itt tartózkodtak, a telep életének nagy részében a csoport eszköz és különböző hegyeket tartalmazó fegyverkészletét igyekeztek feltölteni, megújítani az északról magukkal hozott és a környéken fellelhető nyersanyagok segítségével (Simán 1989: 18). Ezzel a kijelentéssel sem maradéktalanul egyetérteni, sem azzal érdemben vitatkozni nem lehet. Valóban úgy tưnhet hogy az lelőhelyen eltöltött idő alatt elsősorban az eszközök előállítására koncentráltak. Ebből viszont természetesen következik a tény, hogy a retusálatlan pengék, illetve szilánkok és az eszközök aránya nem tükrözi a valóságot, hiszen az elkészült szerszámok és fegyverek legnagyobb részét nyilvánvalóan magukkal vitték. A lelőhelyek ezek alapján csak a felesleges darabok maradtak. Esetleg ez a tény is megmagyarázhatja a törött pengék magas számarányát, az ép pengék legalább egy részét feltehetően elszállították. Ugyanakkor a lelöhely jellegének interpretálását nem kis mértékben megnehezíti a lelöhelyen maradt eszközök, különösen a retusált pengék magas száma (156 db).

Hidasnémeti besorolásáról a Gravettien kultúrkörbe, és Simán Katalin által 25-24 ka BP környékére történő datálásáról már szó esett. Ezen belül a vállas hegyek jelenléte miatt a Pavlovient követő vállas hegyek horizontját, a WillendorfienKostienkient (Svoboda 2007) képviselné Magyarországon. J. K. Kozłowski elmélete szerint a vállas hegyek horizontjának idejében a Gravettien entitás telepei egy egységes rendszer részeit képezték. Az egyes rendkívül specializált települések, amelyek mind egy-egy funkciót láttak el, összeköttetésben álltak egymással, és egy szervezett hálózat részei voltak (Kozłowski 1996: 19). Ebbe a képbe Hidasnémeti-Borház-dúlő is beleilleszthető, amennyiben a megtelepedés elsődleges célja az eszközkészlet felfrissítése volt. Ha viszont ez a feltételezés elfogadható, akkor ez a horizont egyik legdélibb, eddig szinte példa nélküli képviselője hazánkban, egykori hordozói talán új nyersanyagforrásokat kutatva merészkedtek ilyen messzire a központi területtől. J. K. Kozłowski véleménye alapján Hidasnémeti leletegyüttese technológiai és tipológiai szempontból is eltér a dél-lengyelországi leletegyüttesektől (a vállazás hosszának aránya a hegy teljes hosszához képest, a felületi retusálás és a Kostienkien típusú csonkítások hiánya, a vésők alacsony száma és eltérő típusai), közelebb áll a nyugat-szlovákiai leletegyüttesekhez. Ugyanakkor az erratikus és volhíniai tüzkő jelenléte mind északi, mind keleti irányú kapcsolatokra utal (Kozłowski 2008: 188).

A Cserhát-hegység területén található PüspökhatvanÖregszőlő lelőhelyen, amelynek ásatására 1992-ben Csongrádi-Balogh Éva és T. Dobosi Viola vezetésével került sor, egy-egy db töredékes vállas hegy és nyeles hegy is előkerült
(Csongrádi-Balogh, T. Dobosi 1995: 52, Fig 9:1.2). A lelőhelyet a feltárók a helyi hidrokvarcit nyersanyag feldolgozására települt nagyobb kiterjedésű múhely egy részének tekintik. Faszén minta ${ }^{14} \mathrm{C}$ mérése alapján a lelőhely kora $27700 \pm 300 \mathrm{BP}$ (Deb-1901), amely a lelőhelyet a Gravettien entitás régebbi pengés fílumába helyezi (Csongrádi-Balogh, T. Dobosi 1995: 57). Lengyel György véleménye alapján azonban csak a minta típusa és a kormeghatározás ismert, de nem a mintavételezés részletei. A lelőhelyen tűzhely illetve jó megtartású faszén fennmaradását is megkérdőjelezi, amely folytán a minta nem kapcsolható egyértelmúen megtelepüléshez (Lengyel 2009: 258). A kérdésben nem tudunk, és nem kívánunk állást foglalni. Lengyel György feltételezéséből azonban implicite következik, hogy a lelőhely esetleg ténylegesen fiatalabb. A kérdéshez kapcsolódóan itt szükséges megemlíteni, hogy Püspökhatvan-Öregszőlő lelőhelytől ÉÉK irányban mintegy 1 km távolságra elhelyezkedő Püspökhatvan-Takács-hegy eddig publikálatlan 5785 darabos leletanyagában ugyancsak található egy vállas hegy töredéke (Bálint 2015: 32, 67, 23. ábra).

\section{Irodalomjegyzék}

Bálint Cs. 2015. Püspökhatvan-Takács-hegy paleolit leletanyagának tipológiai és nyersanyag elemzése a magyarországi Gravettien kontextusában. Egyetemi szakdolgozat. Kézirat ELTE-BTK Budapest.

Belayeva, V. J. 1977. Opyt sozdania metodiki opisania 'nozhey kostenkovskogo tipa'. In: Problemy paleolita Vostochnoy $i$ Tsentralnoy Europy. Leningrad, 1977.

Bosznay, Á. 2008. Vértes László matematikai statisztikai munkásságáról. Archeometriai Műhely 2008/2, 7-10.

Chakravarti, I. M, Laha, R. L. 1967. Handbook of Methods of Applied Statistics, Volume I. John Wiley and Sons, 392-394.

Csongrádi-Balogh É., T. Dobosi V. 1995. Palaeolithic settlement traces near Püspökhatvan. Folia Archaeologica 44: 37-59.

Deller, D. B., Ellis, C. J. 2001. Evidence for Late Paleoindian Ritual from the Caradoc Site (AfHj-104), Southwestern Ontario, Canada. American Antiquity 66 (2): 267-284. https://doi.org/10.2307/2694608

D'Agostino, R. B. 1970. Transformation to normality of the null distribution of g1. Biometrika 57 (3): 679-681. https://doi. org/10.2307/2334794

D’Agostino, R. B., Belanger, A., D’Agostino, Jr. R. B 1990. A suggestion for using powerful and informative tests of normality (PDF). The American Statistician 44 (4): 316-321. https://doi.org/10.2307/2684359

Eleki F. 2010. Hidasnémeti-Borház-dúlő paleolit leletanyagának tipológiai-technológiai elemzése a hazai Gravettienek kontextusában. Egyetemi szakdolgozat. Kézirat ELTE-BTK Budapest.

Haesaerts, P., Damblon, F., Bachner, M., Trnka, G. 1996. Revised stratigraphy and chronology of the Willendorf II sequence, Lower Austria. Archaeologia Austriaca 80: 25-42.

Holló Zs., Lengyel Gy., Mester Zs., Szolyák P. 2004. Egy pattintott kőeszköz vizsgálata. Magyar kifejezések a technológiai vizsgálatokhoz 3. Ösrégészeti Levelek 6: 62-80.

Inizan, M.-L., Reduron-Ballinger, M., Roche, H., Tixier, J. 1995. Technology de la Pierre taillée. CREP, Meudon

Inizan, M.-L., Reduron-Ballinger, M., Roche, H., Tixier, J. 1999. Technology and Termonology of Knapped Stone. CREP, Meudon

Kaminska, L., Kozłowski, J. K. 2011. Nitra I-Čermáň v rámci štruktúry osídlenia gravettienskej kultúry na Slovensku. Slovenská archeológia (Slovak Archaeology) 1(59): 1-85.

Klíma, B. 1976. Le pavlovien. In: Périgordien et gravettien en Europe. UISPP, IXe Congres. Éd. par.: Bohuslav Klíma, 128-141. 
Kofidou, F. 2009. Lithics and Personhood in the Lateglacial of north west Europe. Thesis for the degree of Doctor of Philosophy. University of Southampton. Faculty of Law, Arts and Social Sciences.

Kozłowski, J.K. 1984. Les lames amenagées par la technique de Kostenki dans le Périgordien de Corbiac. Archaeologia Interregionalis (1984) 31-78.

Kozłowski, J. K. 1996: The Danubian Gravettian as seen from the northern perspective. In: Svoboda, J. (ed.), Paleolithic in the Middle Danube Region. Anniversary volume to Bohuslav Klíma. Arheologický ústav AV ČR, Brno, 11-22.

Kozłowski, J. K. 1998. Taxonomic position of the site in the frame of the Central European Late Gravettian. In: Kozłowski, J. (ed.), Complex of Upper Palaeolithic sites near Moravany, Western Slovakia. Vol. II. Moravany-Lopata II (excavations 1993-1996). Kraków.

Kozłowski, J. K. 2008. The shouldered point horizon and the impact of the LGM on human settlement distribution in Europe. Petrkovice. On Shouldered Points and Female Figurines. The Dolní Vestonice Studies 15: 181-192.

Kozłowski, J. K. 2013. Raw materials procurement in the Late Gravettian of the Carpathian Basin. In: Mester, Zs. (ed.), The Lithic Raw Material Sources and Interregional Human Contacts in the Northern Carpathian Regions. Polish Academy of Arts and Sciences, Kraków-Budapest, 63-85.

Kozłowski, J. K., Sobczyk, K. 1987. The Upper Palaeolithic site KrakówSpadzista Street C2 (Excavations 1980). Kraków, 1987.

Lengyel, Gy. 2009. Radiocarbon dates of the "Gravettian entity" in Hungary. Praehistoria 9: 241-263.

Lengyel, Gy. 2014. Distant connection changes from the Early Gravettian to the Epigravettian in Hungary, In: Otte, M., Le Brun-Ricalens, F. (dir.), Modes de contacts et de déplacements au Paléolithique eurasiatique. E.R.A.U.L. 140, Liège, 331-347.

Lengyel, Gy., Chu, W. 2016. Long thin blade production and Late Gravettian hunter-gatherer mobility in Eastern Central Europe. Quaternary International 406: 166-173. https://doi.org/10.1016/j. quaint.2016.01.020

Lilliefors, H. 1967. On the Kolmogorov-Smirnov test for normality with mean and variance unknown. Journal of the American Statistical Association 62: 399-402. https://doi.org/10.1080/016214 59.1967.10482916

Mester, Zs. 2008-2009. Les outils foliacés de la grotte Jankovich : la renaissance d'un problème ancien. Praehistoria 9-10: 81-98.

Mester, Zs. 2010. Technological analysis of Szeletian bifacial points from Szeleta Cave (Hungary). Human Evolution 24(1-2): 107-124.

Mester, Zs. 2011. A magyarországi középső és felső paleolitikum bifaciális levéleszközeinek technológiája. In: T. Biró, K., Markó, A. (szerk.), Emlékkönyv Violának. Tanulmányok T. Dobosi Viola tiszteletére. Papers in honour of Viola T. Dobosi. Budapest, 2011, 15-41.

Musil, R. 2010. Palaeoenvironment at Gravettian sites in central Europe with emphasis on Moravia (Czech Republic). Quartär 57: 95-123.

Nagy, G. 2013. A miskolci Avas Alsó-Szentgyörgy kőeszközeinek statisztikai vizsgálata. Diplomamunka, Budapest: Eötvös Loránd Tudományegyetem, kézirat.

NIST 2013. NIST/SEMATECH e-Handbook of Statistical Methods, http://www.itl.nist.gov/div898/handbook/index.htm

Pelikán, P. 1986. The Mesozoic siliceous rocks of the Bükk Mountains. In: Papers for the 1st International Conference on Prehistoric Flint Mining and Lithic Raw Material Identification in the Carpathian Basin, Budapest-Sümeg, 177-180.

Pelikán, P. 2002. Földtani felépítés, rétegtani áttekintés. A Bükki Nemzeti Park. Hegyek, erdök, emberek, 23-49.
Přichystal, A. 2010. Classification of lithic raw materials used for prehistoric chipped artefacts in general and siliceous sediments (silicites) in particular: the Czech proposal - Javaslat a pattintott kőeszközök készítésére használt kőeszközök osztályozására, általános tekintetben, különös tekintettel a kovakőzetekre és a kovás üledékekre. Archeometriai Múhely 2013/3: 177-181. http://www. ace.hu/am/2010_3/AM-10-03-AP.pdf

Simán, K. 1986. Jelentés Hidasnémeti-Borházdűlő felsőpaleolitikus telep ásatásáról. A Herman Ottó Múzeum Közleményei 24: 2-4.

Simán, K. 1989. Hidasnémeti - Upper Paleolithic site in the Hernád valley (Northeast Hungary). Acta Archaeologica Carpathica 28: 5-24.

Svoboda, J. 1996. The pavlovian: typology and behaviour. In: Svoboda, J. (ed.), Paleolithic in the Middle Danube Region. Anniversary volume to Bohuslav Klíma. Archeologický ústav AV ČR, Brno, 283-301.

Svoboda, J. 2007. The gravettian on the middle Danube. Spécial table ronde (1ère partie): Le Gravettien entités régionales d'une paléoculture européenne, Les Eyzies, juillet 2004. PALEO. Revue d'archéologie préhistorique 19: 203-220.

T. Biró, K. 1986. The raw material stock for chipped stone artefacts in the Northern Mid-Mountains Tertiary in Hungary. In: Biró, K. T. (ed.), Papers for the 1st International Conference on Prehistoric Flint Mining and Lithic Raw Material Identification in the Carpathian Basin, Budapest-Sümeg. Magyar Nemzeti Múzeum, Budapest, 183-195.

T. Biró, K. 1988. Distribution of lithic raw materials on Prehistoric sites. An interim report. Acta Archaeologica Academiae Scientiarum Hungaricae 40: 251-274.

T. Biró K. 2008a. Kőeszköz nyersanyagok Magyarország területén. Miskolci Egyetem Közleményei, A sorozat, Bányászat 74: 11-37.

T. Biró K. 2008b. Vértes László és a nyersanyagkutatások. Archeometriai Műhely 2008/2: 17-22.

T. Dobosi, V. 1978. A pattintott kőeszközök nyersanyagáról. Folia Archaeologica 29: 7-19.

T. Dobosi, V. (ed.) 2000a. Bodrogkeresztúr-Henye (NE-Hungary), Upper Palaeolithic site. Magyar Nemzeti Múzeum, Budapest

T. Dobosi, V. 2000b. Upper Palaeolithic research in Hungary - a situation report from 2000. Praehistoria 1: 149-159.

T. Dobosi, V., Simán, K. 1996. New Upper Palaeolithic site at Megyaszó-Szelestető. Communicationes Archaeologicae Hungaricae 1996: $5-22$.

Verpoorte, A. 2003. Absolute dates for the Bohemian Middle Upper Palaeolithic. Archeologické rozhledy 55(1): 3-9.

Verpoorte, A. 2009. Chronology of the Gravettian in Bohemia. In: Šída, P. (ed.), The Gravettian of Bohemia. Academy of Sciences of the Czech Republic, Inst. of Archaeology at Brno, Brno, 44-58.

Vértes, L. 1962. Ausgrabungen der Altsteinzeitlichen Siedlung von Arka 1960-61. Acta Archaeologica Academiae Scientiarum Hungaricae 14: 143-157.

Vértes, L. 1964. Das Jungpaläolithikum von Arka in Nord-Ungarn. Quartär 15/16: 79-132.

Vértes, L. 1965. The deposit of silex blades from Boldogkőváralja. Acta Archaeologica Academiae Scientiarum Hungaricae 17: 128-136.

Vértes, L. 1966. The Upper Palaeolithic Site on Mt. Henye at Bodrogkeresztúr. Acta Archaeologica Academiae Scientiarum Hungaricae 18: 3-14.

Vlačiky, M., Michalík, T., Fišáková, M. N., Nývlt, D., Moravcová, M., Králík, M., Kovanda, J., Péková, K., Přichystal, A., Dohnalová, A. 2013. Gravettian occupation of the Beckov Gate in Western Slovakia as viewed from the interdisciplinary research of the Trenčianske Bohuslavice-Pod Tureckom site. Quaternary Inter- 
national 294: 41-60. https://doi.org/10.1016/j.quaint.2011.09.004

Weitzel, C., Colombo, M. 2006. ¿Qué hacemos con los fragmentos? Un experimento en fractura de artefactos líticos tallados. La Zaranda de Ideas 2: 19-33.

Wilczyński, J., Wojtal, P. 2011. Jaksice II-a new Gravettian site in southern Poland. Přehled výzkumů 52: 37-41.

Wilczyński, J., Wojtal, P., Sobczyk, K. 2012. Spatial organization of the Gravettian mammoth hunters' site at Kraków Spadzista (southern Poland). Journal of Archaeological Science 39: 3627-3642. https:// doi.org/10.1016/j.jas.2012.05.012

Wilczyński, J., Wojtal, P., Sobieraj, D., Sobczyk, K. 2015. Kraków Spadzista trench C2: New research and interpretations of Gravettian settlement. Quaternary International 359: 96-113. https://doi.org/10.1016/j.quaint.2014.08.025

Williams-Thorpe, O., Warren, S. E., Nandris, J. G. 1984. The distribution and provenance of archaeological obsidian in Central and Eastern Europe. Journal of Archaeological Science 11: 183-212. https://doi. org/10.1016/0305-4403(84)90001-3

Williams-Thorpe, O., Warren, S. E., Nandris, J. G. 1986. Characterization of obsidian sources and artefacts from Central and Eastern Europe, using instrumental neutron activating analysis. In: Proceedings of the 1st International Conference on Prehistoric Flint Mining and Lithic Raw Material Identification in the Carpathian Basin, Budapest-Sümeg Vol. 2, pp. 271-279. 